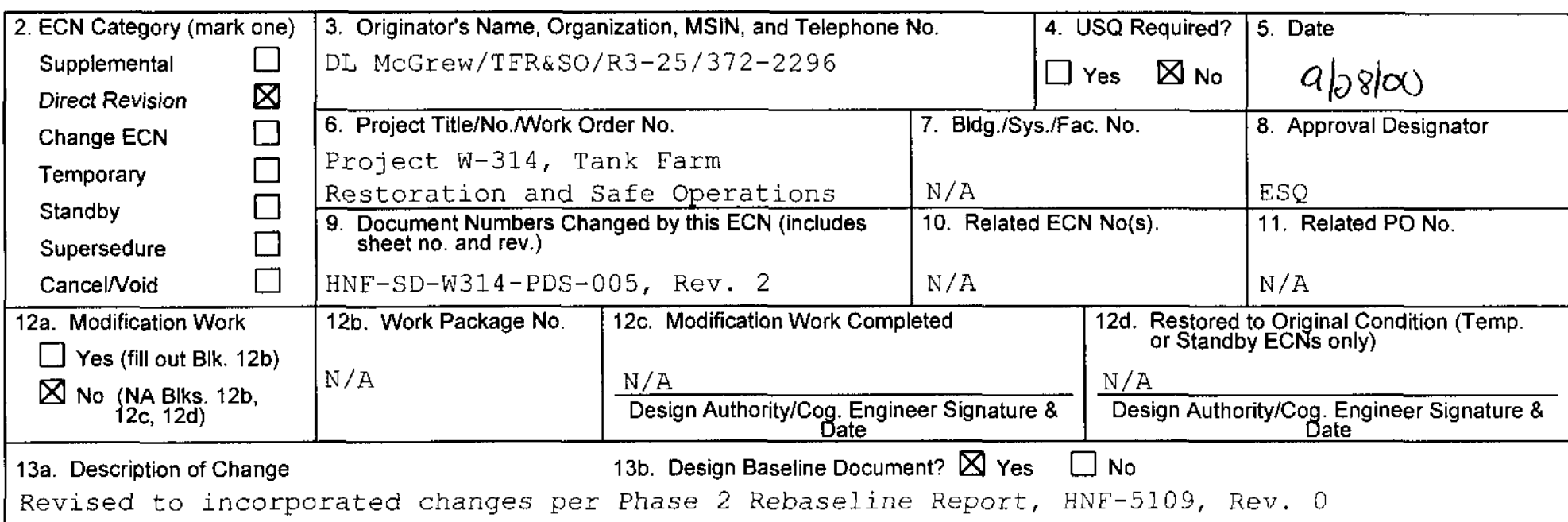

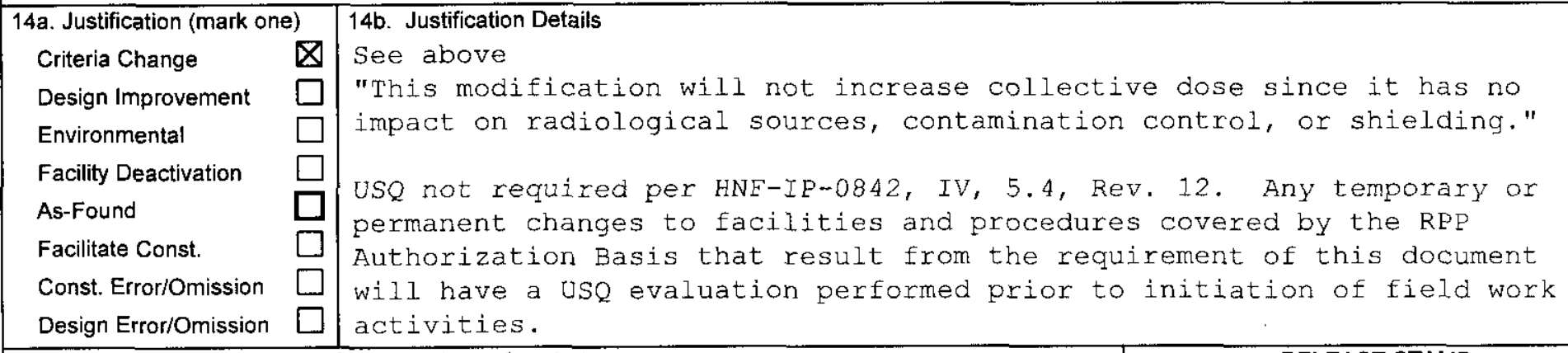




\section{ENGINEERING CHANGE NOTICE}

16. Design Verification 17 . Cost Impact

Required

$\square$ Yes

No
ENGINEERING

Additional $\square \$ \mathrm{~N} / \mathrm{A}$

Savings $\square \$$
Page 2 of 2 CONSTRUCTION

Additional $\square \$ \mathrm{~N} / \mathrm{A}$

Savings $\square \$$

19. Change Impact Review: Indicate the related documents (other than the engineering documents identified on Side 1) that will be affected by the change described in Block 13. Enter the affected document number in Block 20.

$\begin{array}{llll}\text { SDD/DD } & \square & \text { Seismic/Stress Analysis } & \square \\ \text { Functional Design Criteria } & \square & \text { Stress/Design Report } & \square \\ \text { Operating Specification } & \square & \text { Interface Control Drawing } & \square \\ \text { Criticality Specification } & \square & \text { Calibration Procedure } & \square \\ \text { Conceptual Design Report } & \square & \text { Installation Procedure } & \square \\ \text { Equipment Spec. } & \square & \text { Maintenance Procedure } & \square \\ \text { Const. Spec. } & \square & \text { Engineering Procedure } & \square \\ \text { Procurement Spec. } & \square & \text { Operating Instruction } & \square \\ \text { Vendor Information } & \square & \text { Operating Procedure } & \square \\ \text { OM Manual } & \square & \text { Operational Safety Requirement } & \square \\ \text { FSAR/SAR } & \square & \text { IEFD Drawing } & \square \\ \text { Safety Equipment List } & \square & \text { Cell Arrangement Drawing } & \square \\ \text { Radiation Work Permit } & \square & \text { Essential Material Specification } & \square \\ \text { Environmental Impact Statement } & \square & \text { Fac. Proc. Samp. Schedule } & \square \\ \text { Environmental Report } & \square & \text { Inspection Plan } \\ \text { Environmental Permit } & \square & \text { Inventory Adjustment Request } & \square\end{array}$

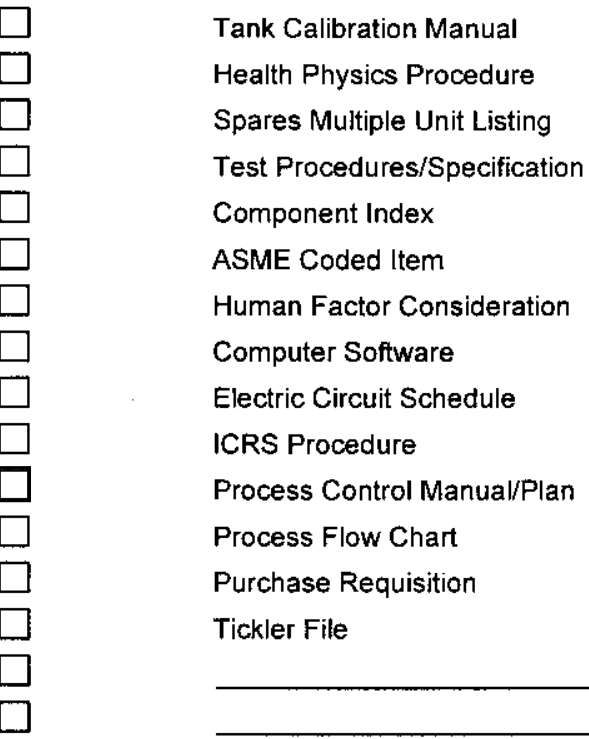

20. Other Affected Documents: (NOTE: Documents listed below will not be revised by this ECN.) Signatures below indicate that the signing organization has been notified of other affected documents listed below.

None

Signature

Date

Design Authority D.E. Bowers D.C. Bowero $9 / 25 / 00$

eog. Eng. D.L. McGrew

Cog. Mgr.

QA

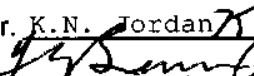
$12 / 2$ and

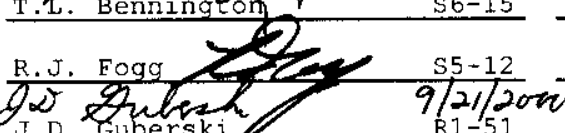

Safety $\frac{\text { R.J. Fogg }}{20 \text { guber }} \frac{55-12}{9 / 21 / 20 n}$

Environ. J.D. Gubersk1

Other

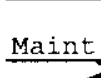

Rad. Con. S.H. Pearue $55.079 / 25 / 2000$

$57-83$

Ops. R.P. Raven a $90-09 / 82$

J.L. Gilbert $1 / 25 /$ oro

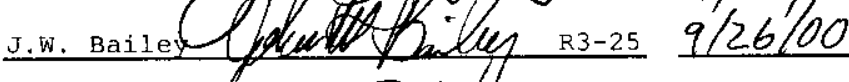

cA Burbe athatamabule e3-25 1/21/2000
Design Agent

PE

QA

Safety

Design

Environ.

Other

\section{DEPARTMENT OF ENERGY}

Signature or a Control Number that tracks the Approval Signature

ADDITIONAL 


\section{DISTRIBUTION SHEET}

To

Distribution

Project TitleMork Order

W-314, Tank Farm Restoration and Safe Operations

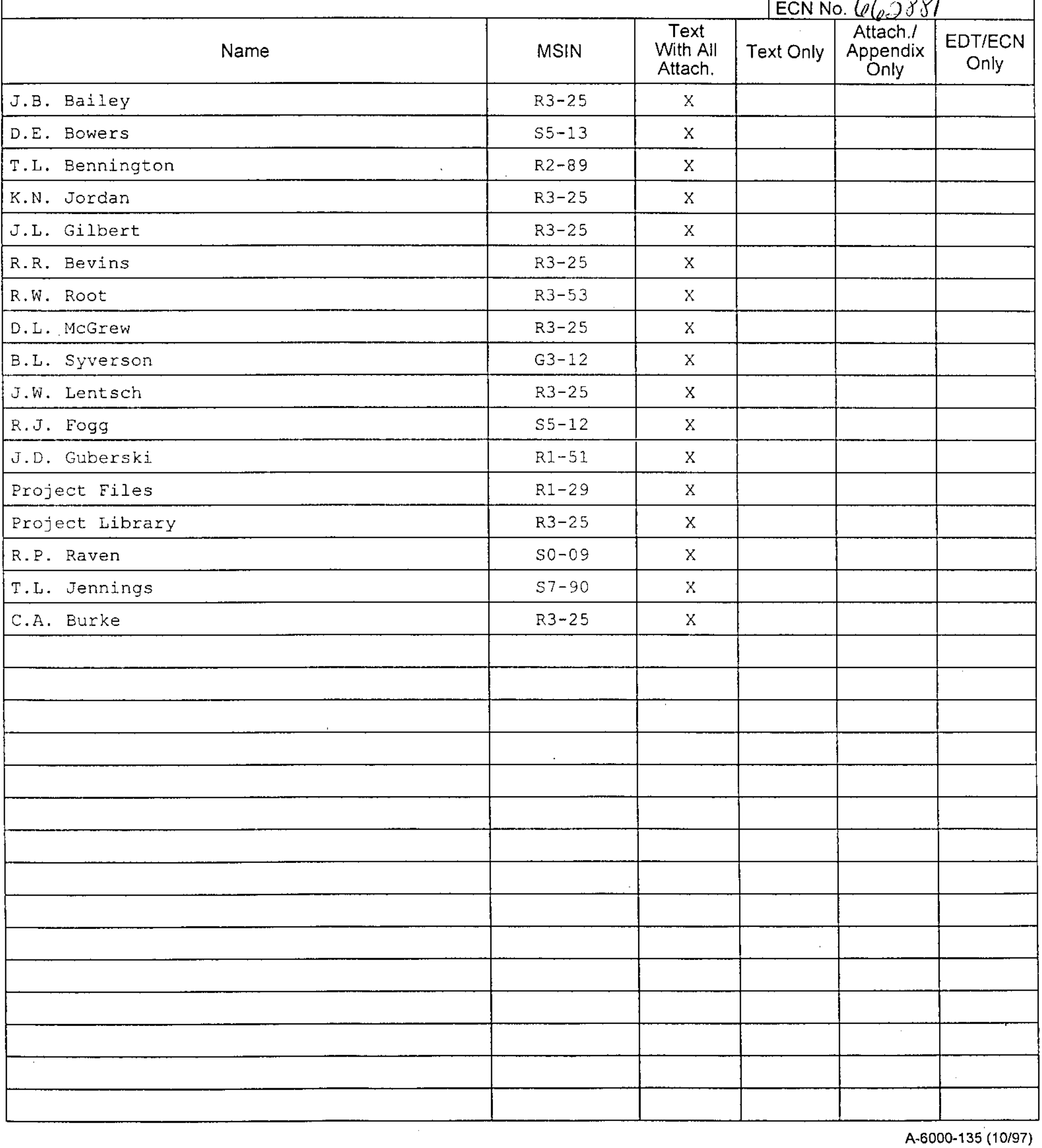

Page 1 of 1
Date $9 / 28 / C 0$

EDT No.

ECN No. 66.0881

From

$+2$

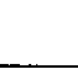




\title{
Project Development Specification for Special Protective Coating
}

\author{
DL McGrew \\ NHC \\ Richland, WA 99352 \\ U.S. Department of Energy Contract DE-AC06-99RL14047 \\ EDT/ECN: $662881 \quad$ UC: \\ Cost Center: 7C900 Charge Code: 199749 \\ B\&R Code: \\ Total Pages: 36 \\ Key Words: Project W-314, Tank Farm Restoration and Safe Operations, \\ Valve Pits, Special Protective Coating

\begin{abstract}
Establishes the performance, design development, and test requirements for the Special Protective Coating. The system engineering approach was used to develop this document in accordance with the guidelines laid out in the Systems Engineering Management Plan for Project $W-314$.
\end{abstract}

TRADEMARK DISCLAIMER. Reference herein to any specific commercial product, process, or service by trade name, trademark, manufacturer, or otherwise, does not necessarily constitute or imply its endorsement, recommendation, or favoring by the United States Government or any agency thereof or its contractors or subcontractors.

Printed in the United States of America. To obtain copies of this document, contact: Document Control Services, P.O. Box 950, Mailstop H6-08, Richland WA 99352, Phone (509) 372-2420; Fax (509) 376-4989.
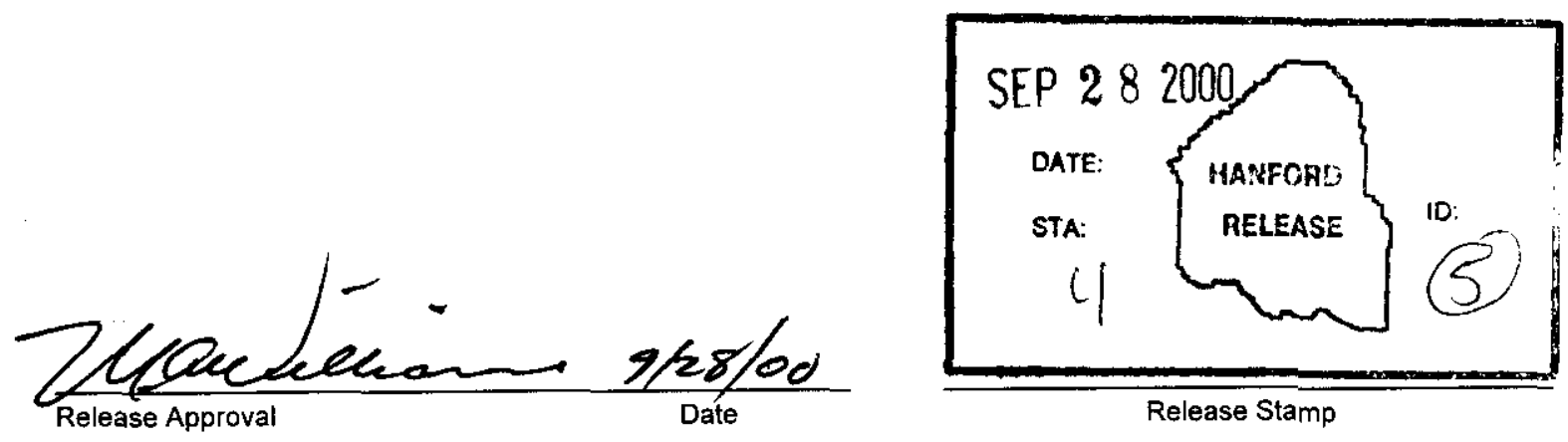

\section{Approved For Public Release}




\section{RECORD OF REVISION}

(2) Title

Project Development Specification for Special Protective Coating

Change Control Record

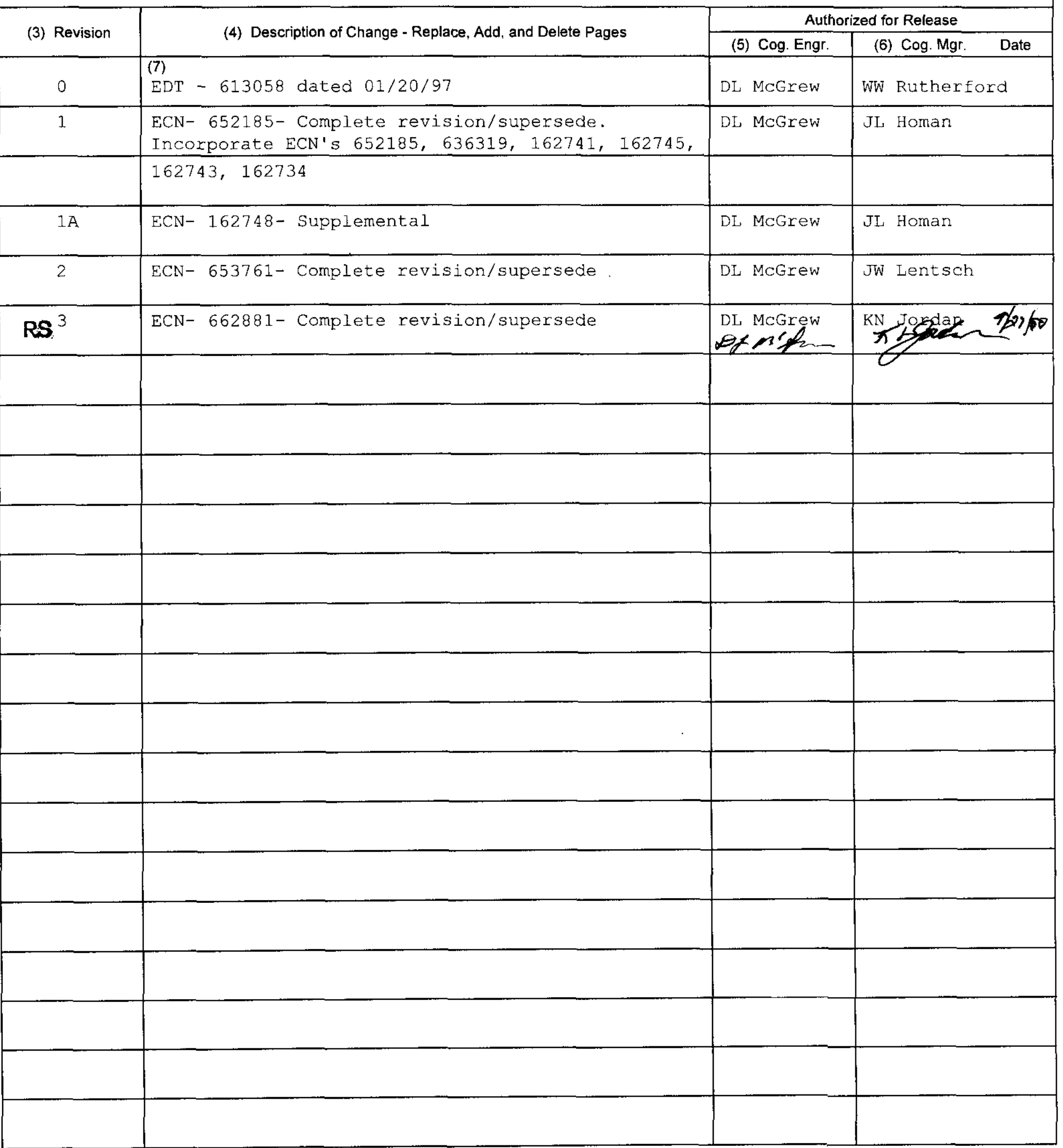




\section{Project Development Specification}

for

\section{Special Protective Coating}

Project W-314

Tank Farm Restoration and Safe Operations

July 2000

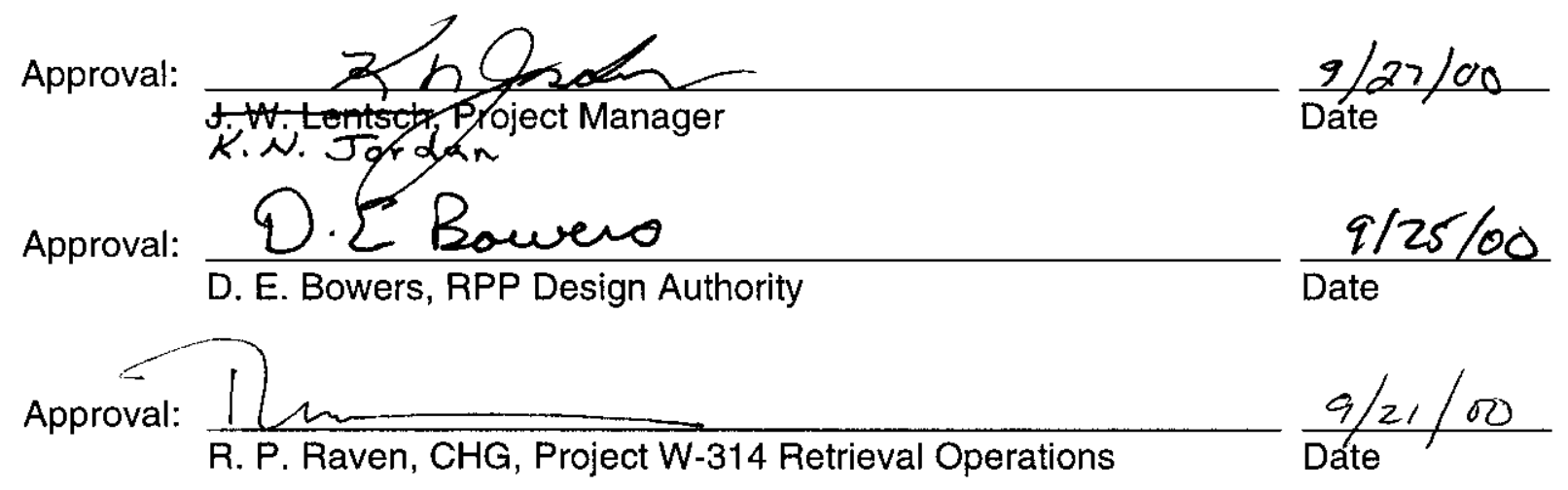




\section{Table of Contents}

1 SCOPE

2 APPLICABLE DOCUMENTS__ 2-1

2.1 DOE Documents__ 2-1

2.2 Code of Federal Regulations___ 2-1

2.3 Tank Farm Contractor Documents___ 2-1

2.4 Project W-314 Documents___ 2-1

2.5 Codes and Standards___ 2-1

2.6 Other Documents__ 2-1

2.7 Drawings_ 2-1

3 REQUIREMENTS__ 3-1

3.1 Item Definition_ 3-1

3.1.1 Item Diagrams_ 3-1

3.1.2 Interface Definition___ 3-1

3.1.2.1 Functional Interface__ 3-1

3.1.2.2 Physical Interfaces__ 3-1

3.1.3 Major Component List_ 3-1

3.2 Characteristics__ 3-1

3.2.1 Performance Characteristics__ 3-1

3.2.1.1 Provide Chemical Resistance__ 3-1

3.2.1.1.1 Chemical Resistance___ 3-1

3.2.1.2 Provide Decontaminability___ 3-3

3.2.1.2.1 Radionuclide Compatibility__ 3-3

3.2.1.2.2 Decontamination Factor__ 3-4

3.2.2 Physical Characteristics___ 3-4

3.2.2.1 Surface Application__ 3-4

3.2.2.2 Thermal Stress Endurance___ 3-4

3.2.2.3 Volatile Organic Content Compliance___ 3-4

3.2.2.4 Tensile Properties___ 3-4

3.2.2.5 Abrasion Resistance___ 3-5

3.2.2.6 Permeability_ 3-5

3.2.2.7 Adhesion to Substrate___ 3-6

3.2.2.8 Color_3-6

3.2.2.9 Labeling Paint__ 3-6

3.2.3 Reliability_ 3-6

3.2.4 Maintainability___ 3-6

3.2.5 Environmental Conditions___ 3-6

3.2.5.1 Natural Environments___ 3-6

3.2.5.1.1 Ambient Air Temperature__ 3-6

3.2.5.1.2 Soil Temperature___ 3-6

3.2.5.1.3 Seismic Loads___ 3-6

3.2.5.1.4 Wind Loads__ 3-6 
3.2.5.1.5 Snow Loads

3.2.5.1.6 Relative Humidity

3.2.5.1.7 Surface Precipitation___ 3-6

3.2.5.1.8 Hail Events___ 3-6

3.2.5.1.9 Sand and Dust___ 3-6

$\begin{array}{lll}3.2 .5 .1 .10 & \text { Solar Radiation_ 3-7 }\end{array}$

3.2.5.1.11 Glaze____ 3-7

$\begin{array}{lll}\text { 3.2.5.1.12 Ashfall Events___ 3-7 } & \text { 3-7. }\end{array}$

3.2.5.1.13 Load Combinations and Allowable Stresses_______ 3-7

$\begin{array}{lll}3.2 .5 .2 & \text { Induced Environments___ 3-7 }\end{array}$

3.2.5.2.1 Waste Properties___ 3-7

3.2.5.2.2 Radiation Tolerance___ 3-7

3.2.5.2.2.1 Inside Pit Radiation Level___ 3-7

3.2.5.2.2.2 Background Radiation Level___ 3-7

3.2.6 Transportability_ 3-7

3.2.7 Flexibility and Expansion__ 3-7

3.3 Design and Construction___ 3-8

3.3.1 Materials, Processes, and Parts___ 3-8

3.3.1.1 Materials___ 3-8

3.3.1.1.1 SPC System_ 3-8

$\begin{array}{lll}3.3 .1 .1 .1 .1 & \text { Service Area_3-8 }\end{array}$

3.3.1.1.1.2 SPC System Schedule___ 3-8

3.3.1.1.2 SPC System Accessory Materials___ 3-8

3.3.1.2 Processes_____ 3-8

3.3.1.2.1 Surface Preparation____ 3-8

3.3.1.2.1.1 Surface Preparation (Excluding Existing Pit Interior SPC Repairs)____ 3-8

3.3.1.2.1.2 Surface Preparation for Existing Pit Interior SPC Repairs___ 3-8

3.3.1.2.2 SPC System Application___ 3-8

3.3.1.3 Optimization___ 3-8

3.3.1.4 Dome Loading____ 3-8

3.3.2 Electromagnetic Radiation___ 3-8

3.3.3 Identification and Marking_______ 3-9

3.3.4 Workmanship___ 3-9

3.3.5 Interchangeability___ 3-9

3.3.6 Safety_ 3-9

3.3.6.1 Material Safety Data Sheets___ 3-9

3.3.6.2 Fire Protection___ 3-9

3.3.6.2.1 Fire Characteristics___ 3-9

3.3.6.2.2 Interior Finishes___ 3-9

3.3.7 Human Performance/Human Engineering___ 3-9

3.4 Documentation___ 3-9

3.4.1 Document Control___ 3-9

3.5 Logistics___ 3-9

3.5.1 Maintenance___ 3-9

3.5.2 Supply_ 3-10

3.5.2.1 Parts and Components__ 3-10 
3.5.3 Facilities and Facility Equipment_ـ 3-10

3.6 Personnel and Training___ 3-10

3.6.1 Personnel__ 3-10

$\begin{array}{ll}\text { 3.6.2 Training___ 3-10 } & \text { 3-10 }\end{array}$

3.7 Major Component Characteristics__ 3-10

4 SYSTEM QUALIFICATION PROVISIONS___ 4-1

4.1 General__ 4-1

4.1.1 Responsibility for Inspections___ 4-1

4.1.2 Special Tests and Examinations___ 4-1

4.2 Quality Conformance Inspections.___ 4-1

5 NOTES___ 5-1

5.1 Definitions___ 5-1

5.1.1 Abrasion Resistance___ 5-1

5.1.2 Adhesion__ 5-1

5.1.3 Chip___ 5-1

5.1.4 Decontamination___ 5-1

5.1.5 Decontamination Factor___ 5-1

5.1.6 Dry-film Thickness___ 5-1

5.1.7 Flaking__ 5-1

5.1.8 Glaze_

5.1.9 Holiday_ 5-1

5.1.10 Laitance___ 5-1

5.1.11 Permeability__ 5-1

5.1.12 Service Level II Area___ 5-2

5.1 .13 Substrate___ 5-2

5.1.14 Wet-Film Thickness____ 5-2

5.1.15 Water Vapor Transmission Rate___ 5-2

5.2 Acronym List_ 5-2

5.3 Applicable Documents___ 5-2

\section{Appendices}

APPENDIX A FUNCTIONAL FLOW BLOCK DIAGRAMS (FFBDS)___ _ A-1

APPENDIX B REQUIREMENTS BASIS___ B-1 
HNF-SD-W314-PDS-005, Rev. 3

\section{List of Tables}

3-1 Chemical Composition Range___ 3-1

3-2 Radionuclide Concentrations__ 3-3

3-3 Tensile Properties of Coatings___ 3-4

3-4 Tensile Properties of Joint Sealants___ 3-5

3-5 Tensile Properties of Fillers___ 3-5

3-6 Abrasion Resistance Properties of Coatings__ 3-5

4-1 Quality Conformance Inspection Matrix 4-3

B-1 Requirements Basis___ B-2 


\section{SCOPE}

This Project Development Specification (PDS) establishes the performance, design development, and test requirements for the Special Protective Coating (SPC). The system engineering approach was used to develop this document in accordance with the guidelines laid out in the Systems Engineering Management Plan (SEMP) for Project W-314.

New SPC will be applied to the new cover blocks provided for Valve Pits 241-AN-A and -B, 241-AW-A and -B, new AZ Valve Pit, and new Slurry Receiver Pit 241-AN-04D, as applicable. In addition, SPC will be applied to the top portion of the $A Z$ Valve Pit walls above the stainless steel liner (i.e., cover block support ledge and above). The SPC shall be repaired where disturbed during the construction process. Additionally, the total SPC in the pits will be examined and repaired as required in the following pits:

- Valve Pits 241-AN-A and -B; 241-AW-A and -B; and 241-SY-A and -B

- Central Pump Pits 241-AY-01A and -02A; 241-AZ-01A and -02A; 241-AN-01A through -07A; 241-AP-01A through -08A; 241-AW-01A through -06A; and 241-SY-01A through -03A

. Drain Pits 241-AP-03D; 241-AW-02D; and 241-SY-02D

- Feed Pump Pits 241-AW-02E and 241-SY-02E 


\section{APPLICABLE DOCUMENTS}

See Section 5.3 for notes regarding applicable documents.

\subsection{DOE Documents}

Not applicable to this specification.

\subsection{Code of Federal Regulations}

Not applicable to this specification.

\subsection{Tank Farm Contractor Documents}

RPP-PRO-224, Document Control Program Standards, Rev. 0.

RPP-PRO-233, Review and Approval of Documents, Rev. 0.

WHC-SD-WM-SARR-016, Tank Waste Compositions and Atmospheric Dispersion Coefficients for use in Safety Analysis Consequence Assessments, Rev. 2.

\subsection{Project W-314 Documents}

HNF-SD-W314-QAPP-001, Quality Assurance Program Plan for Project W-314.

\subsection{Codes and Standards}

ASTM D 4060, Standard Test Method for Abrasion Resistance of Organic coatings by the Taber Abraser.

ASTM D 5144, Standard Guide for Use of Protective Coating Standards in Nuclear Power Plants.

ASTM E-84/NFPA 255, Test Method for Surface Burning Characteristics of Building Materials.

Factory Mutual 1-57, Loss Prevention Data - Rigid Plastic Building Materials.

ICRP Publication 37, Cost Benefit Analysis in the Optimization of Radiological Protection.

\subsection{Other Documents}

WAC 173-303, Dangerous Waste Regulations, 1/98.

\subsection{Drawings}

Not applicable to this specification. 


\section{REQUIREMENTS}

\subsection{Item Definition}

The SPC system consists of filler, joint sealant surfaces, and multiple top coats that forms a solid protective film after application. The solid film isolates the substrate from the environment, as required per WAC 173-303, and provides the decontaminability in areas of secondary confinement, such as pits, subject to radiation exposure and radionuclide contamination.

\subsubsection{Item Diagrams}

Not applicable to this specification.

\subsubsection{Interface Definition}

3.1.2.1 Functional Interface. Not applicable to this specification.

3.1.2.2 Physical Interfaces. The physical interface points are defined to be the interior surfaces of pits consisting of floors, walls, and underside of cover blocks, all exposed surfaces of the pits and cover blocks, and the nozzle locations associated with the existing piping system located within the pits. Stainless steel liners will not be coated with SPC.

\subsubsection{Major Component List}

Not applicable to this specification.

\subsection{Characteristics}

\subsubsection{Performance Characteristics}

The performance requirements of the SPC system are as follows:

\subsubsection{Provide Chemical Resistance}

3.2.1.1.1 Chemical Resistance. The SPC system shall be capable of withstanding the liquid waste chemical composition ranges listed in Table 3-1.

Table 3-1 Chemical Composition Range

\begin{tabular}{|c|c|c|c|c|}
\hline \multirow{2}{*}{ Species } & \multicolumn{3}{|c|}{ DST } & \multicolumn{2}{c|}{ SST } \\
\cline { 2 - 5 } & \multicolumn{2}{|c|}{ Anion/cation } & $\mathrm{min} \mathrm{mol} / \mathrm{L}$ & $\mathrm{max} \mathrm{mol} / \mathrm{L}$ \\
\cline { 2 - 5 } & $\mathrm{min} \mathrm{mol} / \mathrm{L}$ & $\operatorname{max~mol} / \mathrm{L}$ & - & - \\
\hline $\mathrm{Ag}$ & 0 & 0.0013 & 0.029 & 0.5 \\
\hline $\mathrm{Al}$ & 0.05 & 1.1 & - & - \\
\hline $\mathrm{As}$ & 0 & 0.0066 & - & - \\
\hline $\mathrm{B}$ & 0 & 0.013 & & \\
\hline
\end{tabular}


Table 3-1 Chemical Composition Range (Continued)

\begin{tabular}{|c|c|c|c|c|}
\hline \multicolumn{5}{|c|}{ Retrieved waste } \\
\hline \multirow[t]{3}{*}{ Species } & \multicolumn{2}{|c|}{ DST } & \multicolumn{2}{|c|}{ SST } \\
\hline & \multicolumn{2}{|c|}{ Anion/cation } & \multicolumn{2}{|c|}{ Anion/cation } \\
\hline & $\min \mathrm{mol} / \mathrm{L}$ & $\max \mathrm{mol} / \mathrm{L}$ & $\mathrm{min} \mathrm{mol} / \mathrm{L}$ & $\max \mathrm{mol} / \mathrm{L}$ \\
\hline $\mathrm{Ba}$ & 0 & 0.0004 & 0 & 0.0014 \\
\hline $\mathrm{Bi}$ & - & - & 0 & 0.076 \\
\hline $\mathrm{Ca}$ & 0.0014 & 0.1 & 0 & 0.17 \\
\hline $\mathrm{Cd}$ & 0 & 0.0074 & 0 & 0.0007 \\
\hline $\mathrm{Cr}$ & 0.0067 & 0.28 & 0.0001 & 0.091 \\
\hline $\mathrm{Cu}$ & 0 & 0.02 & - & - \\
\hline $\mathrm{Fe}$ & 0.0004 & 0.26 & 0.0057 & 0.89 \\
\hline $\mathrm{Hg}$ & 0 & $2.8 \mathrm{E}-05$ & 0 & 0.0001 \\
\hline K & 0.044 & 0.55 & 0.0002 & 0.0095 \\
\hline La, $\mathrm{Nd}$ & 0 & 0.0066 & 0 & 0.001 \\
\hline $\mathrm{Mg}$ & 0.0004 & 0.046 & - & - \\
\hline $\mathrm{Mn}$ & 0.0003 & 0.16 & 0.0009 & 0.41 \\
\hline Mo & 0 & 0.0029 & - & - \\
\hline $\mathrm{Na}$ & 1.6 & 10.7 & 1.6 & 7.1 \\
\hline $\mathrm{Ni}$ & 0.0002 & 0.008 & 0 & 0.042 \\
\hline $\mathrm{Pb}$ & 0 & 0.004 & 0 & 0.12 \\
\hline $\mathrm{Pd}, \mathrm{Rh}$ & 0 & 0.0063 & - & - \\
\hline $\mathrm{Si}(\mathrm{SiO} 2)$ & 0.0024 & 0.028 & 0.0004 & 0.46 \\
\hline $\mathrm{Ti}$ & 0 & 0.002 & - & - \\
\hline$U$ & 0 & 0.0092 & - & - \\
\hline $\mathrm{Zr}(\mathrm{ZrO} 2)$ & 0 & 0.3 & 0 & 0.065 \\
\hline Acetate & - & - & 0 & 0.0055 \\
\hline Citrate & 0 & 0.03 & 0.0042 & 0.06 \\
\hline EDTA & 0 & 0.016 & 0 & 0.011 \\
\hline HEDTA & 0 & 0.021 & - & - \\
\hline $\mathrm{Fe}(\mathrm{CN}) 6$ & - & $\cdot$ & 0 & 0.025 \\
\hline $\mathrm{Cl}$ & 0.003 & 0.17 & 0 & 0.022 \\
\hline $\mathrm{CO} 3$ & 0.03 & 0.69 & 0.014 & 0.38 \\
\hline $\mathrm{F}$ & 0.014 & 1 & 0.001 & 0.71 \\
\hline
\end{tabular}


Table 3-1 Chemical Composition Range (Continued)

\begin{tabular}{|c|c|c|c|c|}
\hline \multicolumn{4}{|c|}{ Retrieved waste } \\
\hline \multirow{2}{*}{ Species } & \multicolumn{2}{|c|}{ DST } & \multicolumn{2}{c|}{ SST } \\
\cline { 2 - 5 } & \multicolumn{2}{|c|}{ Anion/cation } & Anion/cation \\
\cline { 2 - 5 } & $\operatorname{min~mol/L}$ & $\operatorname{max~mol} / \mathrm{L}$ & $\operatorname{min~mol} / \mathrm{L}$ & $\mathrm{max} \mathrm{mol} / \mathrm{L}$ \\
\hline Fission product & 0 & 0.0001 & - & - \\
\hline $\mathrm{NO} 2$ & 0.1 & 1.8 & 0.0086 & 0.83 \\
\hline $\mathrm{NOX}(\mathrm{NO} 3)$ & 0.15 & 3.6 & 0.64 & 5.1 \\
\hline $\mathrm{OH}$ & 0.24 & 4.4 & 0.25 & 6.9 \\
\hline $\mathrm{PO} 4$ & 0 & 0.4 & 0.0007 & 3.8 \\
\hline $\mathrm{SO} 4$ & 0.003 & 0.16 & 0.01 & 0.22 \\
\hline TOC & 0 & 2 & - & - \\
\hline
\end{tabular}

DST = Double-shell tank

EDTA = Ethylenediametetraacetic acid

HEDTA = n-(hydroxyethyl)-Ethylenediametetraacetic acid

SST = Single-shell tank

TOC $=$ Total organic carbon

\subsubsection{Provide Decontaminability}

3.2.1.2.1 Radionuclide Compatibility. The SPC system shall be compatible with the waste radionuclide concentrations listed under the W-314 column in Table 3-2.

Table 3-2 Radionuclide Concentrations

\begin{tabular}{|c|c|c|c|}
\hline \multirow{2}{*}{ Nuclide } & \multicolumn{3}{|c|}{ Nuclide Concentrations (Bq/L) } \\
\cline { 2 - 4 } & (a)All liquids & (a)All solids & (b)W-314 \\
\hline $14 \mathrm{C}$ & $2.3 \mathrm{E}+05$ & $1.6 \mathrm{E}+05$ & $2.3 \mathrm{E}+05$ \\
\hline $60 \mathrm{Co}$ & $9.5 \mathrm{E}+06$ & $4.9 \mathrm{E}+08$ & $1.7 \mathrm{E}+08$ \\
\hline $79 S e$ & (c) & $1.7 \mathrm{E}+04$ & $1.7 \mathrm{E}+04$ \\
\hline $90 \mathrm{Sr}$ & $1.1 \mathrm{E}+10$ & $2.9 \mathrm{E}+12$ & $9.6 \mathrm{E}+11$ \\
\hline $90 \mathrm{Y}$ & $1.1 \mathrm{E}+10$ & $2.9 \mathrm{E}+12$ & $9.6 \mathrm{E}+11$ \\
\hline $99 \mathrm{Tc}$ & $1.7 \mathrm{E}+07$ & $1.2 \mathrm{E}+10$ & $4.0 \mathrm{E}+09$ \\
\hline $106 \mathrm{Ru}$ & $9.9 \mathrm{E}+02$ & $7.2 \mathrm{E}+04$ & $2.4 \mathrm{E}+04$ \\
\hline $125 S b$ & $3.4 \mathrm{E}+04$ & $1.8 \mathrm{E}+08$ & $5.9 \mathrm{E}+07$ \\
\hline 1291 & $2.0 \mathrm{E}+04$ & $6.4 \mathrm{E}+06$ & $2.1 \mathrm{E}+06$ \\
\hline $134 \mathrm{Cs}$ & $6.1 \mathrm{E}+06$ & $9.4 \mathrm{E}+06$ & $7.2 \mathrm{E}+06$ \\
\hline $137 \mathrm{Cs}$ & $8.8 \mathrm{E}+10$ & $1.0 \mathrm{E}+11$ & $9.2 \mathrm{E}+10$ \\
\hline
\end{tabular}


Table 3-2 Radionuclide Concentrations (Continued)

\begin{tabular}{|c|c|c|c|}
\hline \multirow{2}{*}{ Nuclide } & \multicolumn{3}{|c|}{ Nuclide Concentrations (Bq/L) } \\
\cline { 2 - 4 } & (a)All liquids & (a)All solids & (b)W-314 \\
\hline $144 \mathrm{Ce}$ & $9.1 \mathrm{E}+00$ & $3.4 \mathrm{E}+02$ & $1.2 \mathrm{E}+02$ \\
\hline $147 \mathrm{Pm}$ & $3.6 \mathrm{E}+07$ & $(\mathrm{c})$ & $3.6 \mathrm{E}+07$ \\
\hline $154 \mathrm{Eu}$ & $2.4 \mathrm{E}+09$ & $1.1 \mathrm{E}+10$ & $5.2 \mathrm{E}+09$ \\
\hline $155 \mathrm{Eu}$ & $5.9 \mathrm{E}+07$ & $5.0 \mathrm{E}+06$ & $5.9 \mathrm{E}+07$ \\
\hline $237 \mathrm{~Np}$ & $2.3 \mathrm{E}+05$ & $9.9 \mathrm{E}+08$ & $3.3 \mathrm{E}+08$ \\
\hline $238 \mathrm{Pu}$ & $1.8 \mathrm{E}+06$ & $1.9 \mathrm{E}+08$ & $6.4 \mathrm{E}+07$ \\
\hline $239 \mathrm{Pu}(\mathrm{d})$ & $3.6 \mathrm{E}+07$ & $1.6 \mathrm{E}+09$ & $5.5 \mathrm{E}+08$ \\
\hline $241 \mathrm{Pu}$ & $2.6 \mathrm{E}+08$ & $3.8 \mathrm{E}+09$ & $1.4 \mathrm{E}+09$ \\
\hline $241 \mathrm{Am}$ & $4.2 \mathrm{E}+07$ & $1.1 \mathrm{E}+10$ & $3.7 \mathrm{E}+09$ \\
\hline $242 \mathrm{Cm}$ & $1.1 \mathrm{E}+01$ & $2.0 \mathrm{E}+02$ & $7.3 \mathrm{E}+01$ \\
\hline $244 \mathrm{Cm}$ & $4.2 \mathrm{E}+05$ & $6.1 \mathrm{E}+07$ & $2.0 \mathrm{E}+07$ \\
\hline
\end{tabular}

(a) From Table 1a., Van Keuren, J. C., 1996, Tank Waste Compositions and Atmospheric Dispersion Coefficients for Use in Safety Analysis Consequence Assessments, WHC-SD-WM-SARR-016, Rev. 2, Westinghouse Hanford Company, Richland, Washington.

(b) W-314 values represent a bounding mixture for design of $67 \%$ liquid and $33 \%$ solid, except for $14 \mathrm{C}$ and $155 \mathrm{Eu}$ where the maximum liquid value was used as it is higher than the mix and for $79 \mathrm{Se}$ and 147Pm where data is not available.

(c) No available data.

(d) The 239Pu activity concentration also includes $240 \mathrm{Pu}$.

3.2.1.2.2 Decontamination Factor. The top coating of the SPC system shall demonstrate relative ease of decontamination with a minimum Decontamination Factor (DF) of 100. The DF after initial water wash shall be a minimum of 20 .

\subsubsection{Physical Characteristics}

3.2.1 Surface Application. The SPC system shall develop the ability to resist the development of holidays with time.

3.2.2.2 Thermal Stress Endurance. The SPC system shall successfully fill or bridge cracks of $1.0-1.5 \mathrm{~mm}(0.040-0.060$ inches) caused by thermal movement and stresses within concrete.

3.2.2.3 Volatile Organic Content Compliance. The SPC system shall be volatile organic content (VOC) compliant with a maximum VOC of $2.9 \mathrm{lbs} /$ gallon (350 grams/liter).

3.2.2.4 Tensile Properties. The SPC system shall have minimum acceptable tensile properties tabulated in Table $3-3$, and -4 , and -5 . 
Table 3-3 Tensile Properties of Coatings

\begin{tabular}{|l|l|l|}
\hline Properties & Rigid Coating (Epoxy) & $\begin{array}{l}\text { Flexible Coating } \\
\text { (Elastomeric) }\end{array}$ \\
\hline Tensile Strength & N/A & $\begin{array}{l}\text { Minimum 20,700 KPa (3,000 } \\
\text { psi) at 30 days }\end{array}$ \\
\hline $\begin{array}{l}\text { Elongation at break at } \\
24^{\circ} \mathrm{C}\left(75^{\circ} \mathrm{F}\right)\end{array}$ & Minimum 5 percent & $\begin{array}{l}\text { Minimum 400 percent at 30 } \\
\text { days }\end{array}$ \\
\hline
\end{tabular}

Table 3-4 Tensile Properties of Joint Sealants

\begin{tabular}{|l|l|l|}
\hline Properties & Flexible Epoxy & $\begin{array}{l}\text { Fluoroelastomer, Polysulfide, } \\
\text { Polyurethane }\end{array}$ \\
\hline Tensile Strength & $\begin{array}{l}\text { Minimum 3,500 KPa (500 } \\
\text { psi) }\end{array}$ & $\begin{array}{l}\text { Minimum 10,400 KPa (1,500 } \\
\text { psi) }\end{array}$ \\
\hline $\begin{array}{l}\text { Elongation at break at } \\
24{ }^{\circ} \mathrm{C}\left(75^{\circ} \mathrm{F}\right)\end{array}$ & Minimum 100 percent & Minimum 100 percent \\
\hline
\end{tabular}

Table 3-5 Tensile Properties of Fillers

\begin{tabular}{|l|l|}
\hline Properties & Solid Epoxy Mastic \\
\hline Tensile Strength & Minimum 3,500 KPa (500 psi) \\
\hline Elongation at break at & Minimum 20 percent \\
$24^{\circ} \mathrm{C}\left(75^{\circ} \mathrm{F}\right)$ & \\
\hline
\end{tabular}

3.2.2.5 Abrasion Resistance. The top coating shall demonstrate the abrasion resistance property. The acceptable abrasion resistance values of the installed coating are tabulated in Table 3-6. The weight loss values are for 1000 cycles when a CS-17 wheel is used with a 1000 $\mathrm{g}$ load in accordance with ASTM D 4060.

Table 3-6 Abrasion Resistance Properties of Coatings

\begin{tabular}{|l|l|l|}
\hline Properties & Rigid Coating (Epoxy) & $\begin{array}{l}\text { Flexible Coating } \\
\text { (Elastomeric) }\end{array}$ \\
\hline Abrasion Resistance & Weight loss less than $100 \mathrm{mg}$ & Weight loss less than $10 \mathrm{mg}$ \\
\hline
\end{tabular}

3.2.2.6 Permeability. The SPC system shall be capable of resisting the migration of liquid waste/water into the pit wall. The permeability shall be measured as follows:

. The maximum water vapor transmission (WVT) rate for a top coating shall be $8 \mathrm{gm} / \mathrm{square}$ meter/24 hr.

. The maximum water absorption rate for a top coating and joint sealant shall be 0.5 percent 
per 24 hours.

3.2.2.7 Adhesion to Substrate. The SPC system shall display an adhesion property to the underlying concrete and previously coated surfaces. Minimum pull-off strength shall be 6,200 $\mathrm{KPa}(900 \mathrm{psi})$. Existing pit interior SPC repairs are excluded from this requirement when ALARA considerations prevent surface preparation per manufacturer's recommendations.

3.2.2.8 Color. The color of the top coat shall be white or near white such that nozzle labels and markers can be painted over the top coat.

3.2.2.9 Labeling Paint. Paint (coating) use for identification marking on the SPC top coat shall be compatible with the SPC system.

\subsubsection{Reliability}

The SPC system shall have a design life of 12 years when installed per the manufacturer's recommendations.

\subsubsection{Maintainability}

The SPC system shall be repairable for cracks appearing through the applied coated surface to the substrate or for chips and flaking on account of mechanical damage.

\subsubsection{Environmental Conditions}

The systems and components covered by this specification shall be compatible with the environmental conditions listed below, as applicable.

\subsubsection{Natural Environments}

3.2.5.1.1 Ambient Air Temperature. The ambient air temperature range is $48.9^{\circ} \mathrm{C}\left(120^{\circ} \mathrm{F}\right)$ to $-35.5^{\circ} \mathrm{C}\left(-32^{\circ} \mathrm{F}\right)$, and with a maximum 24 hour differential of $28.9^{\circ} \mathrm{C}\left(52^{\circ} \mathrm{F}\right)$.

3.2.5.1.2 Soil Temperature. Not applicable to this specification.

3.2.5.1.3 Seismic Loads. Not applicable to this specification.

3.2.5.1.4 Wind Loads. Not applicable to this specification.

3.2.5.1.5 Snow Loads. Not applicable to this specification.

3.2.5.1.6 Relative Humidity. The relative humidity range is 0 to $100 \%$ (Rate of change is negligible).

3.2.5.1.7 Surface Precipitation. The surface precipitation is $4 \mathrm{~cm}$ ( 1.56 in) in a 24 hour period.

3.2.5.1.8 Hail Events. The hail diameter is less than or equal to $1.9 \mathrm{~cm}(0.75 \mathrm{in})$.

3.2.5.1.9 Sand and Dust. The sand/dust concentration is $0.177 \mathrm{gm} /$ cubic meter with a 
typical size of $350 \mu \mathrm{m}$.

3.2.5.1.10 Solar Radiation. The solar radiation range is between 4 Watts/square meter and 406 Watts/square meter.

3.2.5.1.11 Glaze. (See definition is Section 5.1) The glaze is $2.54 \mathrm{~cm}(1 \mathrm{in}$.).

3.2.5.1.12 Ashfall Events. Not applicable to this specification.

3.2.5.13 Load Combinations and Allowable Stresses. Not applicable to this specification.

\subsubsection{Induced Environments}

3.2.5.2.1 Waste Properties. Materials used that come in contact with the waste shall be capable of safely handling waste with the following properties:

$\begin{array}{ll}\text { Specific Gravity } & 1 \text { to } 1.5 \\ \text { Viscosity } & 1 \text { to } 30 \text { centipoise (Newtonian) } \\ \text { Miller Number } & 100 \text { Maximum } \\ \text { pH } & 7 \text { to } 14 \\ \text { Temperature } & 10 \text { to } 93{ }^{\circ} \mathrm{C}\left(50 \text { to } 200^{\circ} \mathrm{F}\right) \\ \text { Solids Content } & 30 \mathrm{Vol} \% \\ \text { Particle Size } & 0.5 \text { to } 4000 \text { microns }\end{array}$

Note: $95 \%$ of total particles 0 to 50 microns $<5$ percent of total particles 50 to 500 microns $<1$ percent of total particles 500 to 4000 microns

\subsection{Radiation Tolerance}

3.2.5.2.1 Inside Pit Radiation Level. Materials used that are located inside a pit shall be capable of operating in the following radiation environment:

total accumulated dose: $\quad 6.0 \mathrm{E}+7$ rads
dose rate:
$1.0 \mathrm{E}+7 \mathrm{mr} / \mathrm{hr}$

3.2.5.2.2 Background Radiation Level. Materials used that are located outside a pit, above ground, shall be capable of operating in the following radiation environment:
total accumulated dose:
$4.4 \mathrm{rad} /$ year
dose rate:
$0.5 \mathrm{mrem} /$ hour

\subsubsection{Transportability}

Not applicable to this specification.

\subsubsection{Flexibility and Expansion}

Each system design shall, to the maximum extent practicable, provide sufficient flexibility to accommodate for programmatic changes or operation modifications. 


\subsection{Design and Construction}

\subsubsection{Materials, Processes, and Parts}

\subsubsection{Materials}

\subsection{SPC System}

3.3.1.1.1 Service Area. The SPC system shall be suitable for Service Level II Area.

3.3.1.1.1.2 SPC System Schedule. A SPC system schedule shall be prepared during definitive design stage, based on manufacturer recommendations, published data for the SPC system and field ALARA conditions. The schedule shall provide descriptions of prime, base, intermediate, and finish coats as applicable; minimum dry film thickness in mils; and color.

3.3.1.1.2 SPC System Accessory Materials. Coating accessory materials such as joint sealants, fillers, primers, thinners, form release agents, and scrim cloth shall be as recommended by the manufacturer of the SPC system suitable for environmental conditions specified in this document.

\subsubsection{Processes}

\subsection{Surface Preparation}

3.3.1.2.1.1 Surface Preparation (Excluding Existing Pit Interior SPC Repairs). The design document will incorporate a surface preparation procedure prepared in consultation with the manufacturer of the SPC system. Substrate preparation method(s) and acceptance criteria will be selected and documented in the design media during the design phase.

3.3.1.2.1.2 Surface Preparation for Existing Pit Interior SPC Repairs. The design document will incorporate a surface preparation procedure prepared in consultation with the manufacturer of the SPC system when field radiological/toxicological conditions permit. When field radiological/toxicological conditions prohibit surface preparation per manufacturer's consultation, the design document will provide minimum surface preparation details consistent with ALARA.

3.3.1.2.2 SPC System Application. The SPC system shall be installed only when ambient and surface temperatures are within the range recommended by the coating manufacturer for the respective coating. The application procedure for the SPC system shall be in accordance with the manufacturers' specification.

3.3.1.3 Optimization. During the design of facilities, optimization principles, as discussed in ICRP Publication 37 , shall be utilized in developing and justifying facility design and physical controls.

3.3.1.4 Dome Loading. The equipment used for installation and maintenance shall comply with the DST dome loading constraints.

\subsubsection{Electromagnetic Radiation}


Not applicable to this specification.

\subsubsection{Identification and Marking}

Not applicable to this specification.

\subsubsection{Workmanship}

Not applicable to this specification.

\subsubsection{Interchangeability}

Not applicable to this specification.

\subsubsection{Safety}

3.3.6.1 Material Safety Data Sheets. Material Safety Data Sheets (MSDS) for the SPC system components shall be furnished during the data transmittal review stage for approval. Obtain inspection and acceptance by the construction engineer before opening containers or removing labels.

\subsubsection{Fire Protection}

3.3.6.2.1 Fire Characteristics. Any materials with unusual fire characteristics, such as urethane foams, and any materials that develop significant quantities of toxic or other harmful products of combustion, shall not be used as interior finishes or other interior applications without the approval of the cognizant DOE fire protection authority. The use of foamed plastics in construction shall be prohibited unless it fully complies with Factory Mutual 1-57.

3.3.6.2.2 Interior Finishes. Nuclear facilities and laboratories shall have interior finish materials (decorations, furnishings, and exposed wall or insulating material) that have an Underwriters Laboratories (ASTM E-84/NFPA 255) flame spread rating of 25 or less, and smoke developed rating of 50 or less.

\subsubsection{Human Performance/Human Engineering}

Not applicable to this specification.

\subsection{Documentation}

\subsubsection{Document Control}

Records, documents, and document control pertinent to design functions shall be in accordance with RPP-PRO-224 and RPP-PRO-233.

\subsection{Logistics}

\subsubsection{Maintenance}


Not applicable to this specification.

\subsubsection{Supply}

3.5.2.1 Parts and Components. The system design shall, to the greatest extent practicable, use readily available parts and components.

\subsubsection{Facilities and Facility Equipment}

Not applicable to this specification.

\subsection{Personnel and Training}

\subsubsection{Personnel}

Not applicable to this specification.

\subsubsection{Training}

Not applicable to this specification.

\subsection{Major Component Characteristics}

Not applicable to this specification. 


\section{SYSTEM QUALIFICATION PROVISIONS}

\subsection{General}

The Project W-314 QAPP (HNF-SD-W314-QAPP-001) defines the quality assurance requiremnts for this project.

Table 4-1 listed verifications may be performed in conjunction with QAPP verifications. Inspections as defined in 4.2 shall be conducted during the design and development of each system to provide assurance of compliance with the requirements of this PDS.

\subsubsection{Responsibility for Inspections}

The design contractor shall be responsible for the performance of all inspections for each system developed in accordance with this PDS. Inspections shall be conducted at the contractor facilities or the facilities of his choice with the approval of the procuring authority. The procuring authority reserves the right to witness or perform the specified inspections.

\subsubsection{Special Tests and Examinations}

Not applicable to this specification.

\subsection{Quality Conformance Inspections.}

Qualification shall be performed on System hardware representative of the approved production design. Qualification of the System to assure compliance with the requirements of Section 3 shall be by examination, demonstration, test, and/or analysis, as defined herein. Test program data may be used to assure compliance with requirements.

a. Examination is an element of inspection consisting of investigation, without the use of special laboratory appliances or procedures, to determine compliance with requirements. This method is intended to be construction related and consists of examination of documents and construction activities.

b. Demonstration is an element of inspection that is limited to readily observable functional operation to determine compliance with requirements. This element of inspection does not require the use of special equipment or sophisticated instrumentation. This method is intended to be utilized for any mock-up testing.

c. Test is an element of inspection that employs technical means including (but not limited to) the evaluation of functional characteristics by use of special equipment or instrumentation, simulation techniques, and the application of established principles and procedures to determine compliance with requirements. The analysis of data derived from test is an integral part of this inspection. This method is intended to be utilized for any acceptance testing in the field.

d. Analysis is an element of inspection, taking the form of the processing of accumulated results and conclusions, intended to provide proof that verification of a requirement(s) has been accomplished. The analytical results may be comprised of a compilation of interpretation of 
existing information or derived from lower level examinations, tests, demonstrations, or analyses.

The environmental capability of equipment shall be demonstrated by appropriate testing, analysis, and operating experience, or other methods that can be supported by auditable documentation, or a combination of these methods. 
HNF-SD-W314-PDS-005, Rev. 3

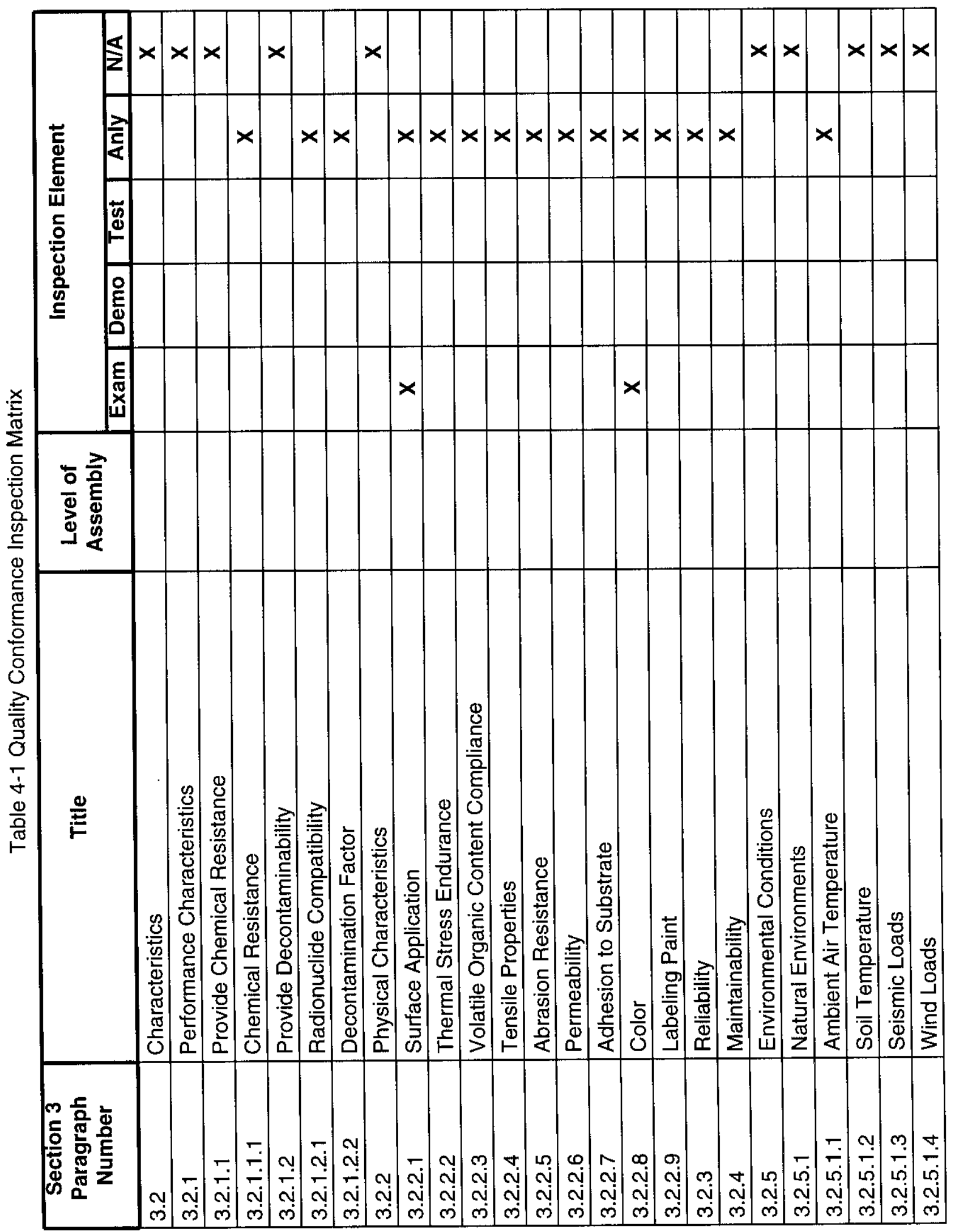




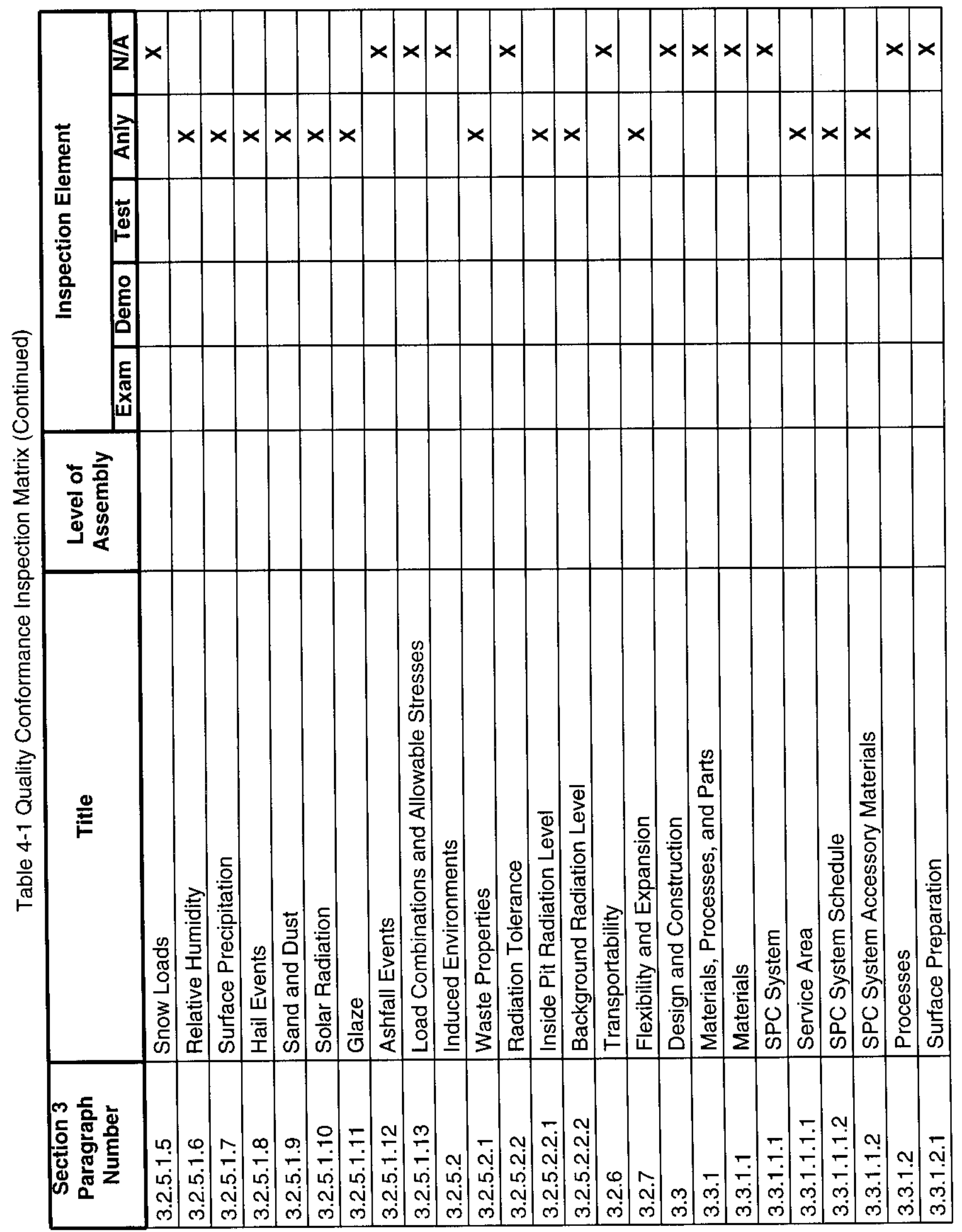




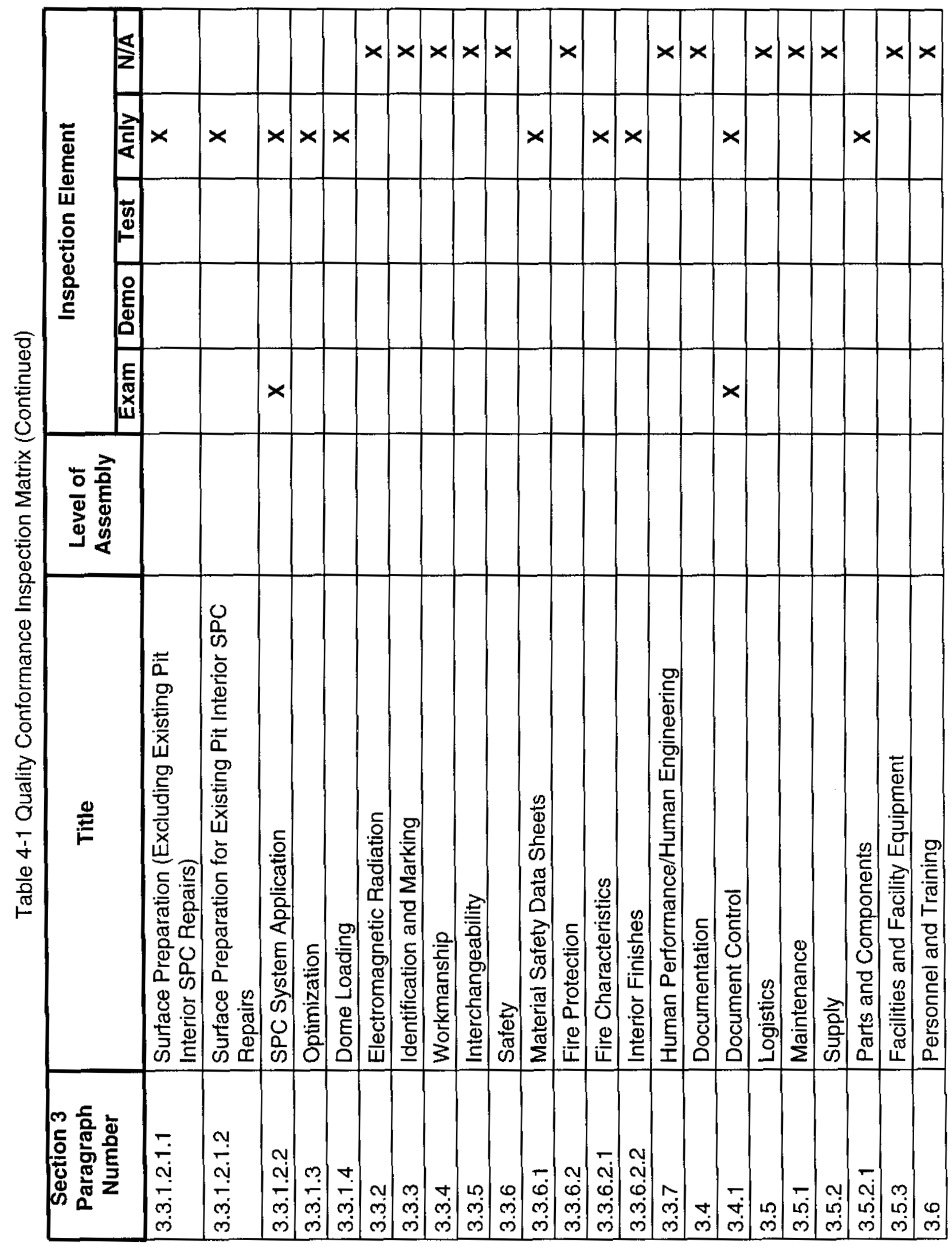


HNF-SD-W314-PDS-005, Rev. 3

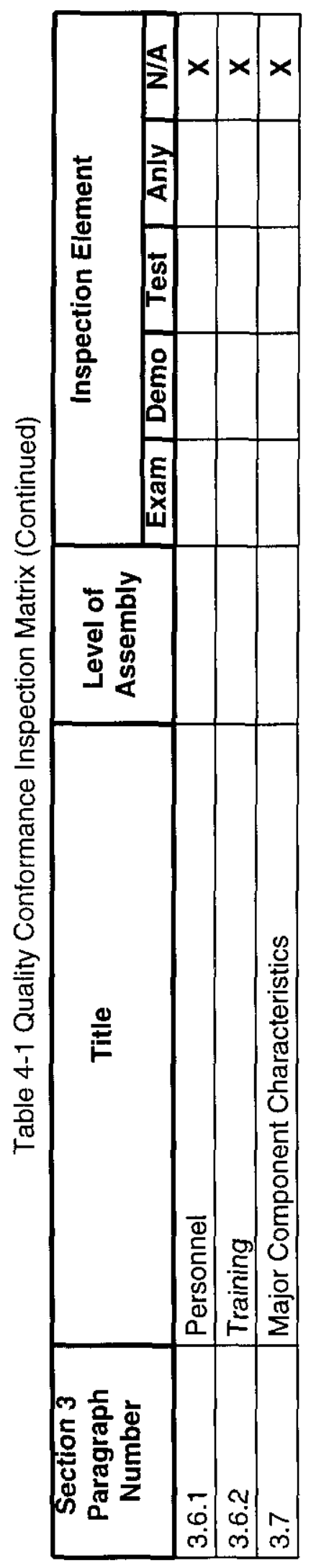




\section{NOTES}

\subsection{Definitions}

\subsubsection{Abrasion Resistance}

The property of a surface by which it resists being worn away as the result of friction.

\subsubsection{Adhesion}

The bond or attraction of a coat of paint to the underlying material, such as a substrate or another coat.

\subsubsection{Chip}

The detachment of small pieces of the substrate.

\subsubsection{Decontamination}

The act of removing radioactive nuclides from a surface.

\subsubsection{Decontamination Factor}

The ratio of the original number of radioactive nuclides on the surface of a specimen to the number remaining after a decontamination process.

\subsubsection{Dry-film Thickness}

Depth of applied coating when dry, expressed in mils (0.001 in).

\subsubsection{Flaking}

The detachment of small pieces of the coating film.

\subsubsection{Glaze}

Coating of ice formed when rain or drizzle freezes on contact with any surface having a temperature that is below freezing.

\subsubsection{Holiday}

Pinhole, skip, discontinuity, or a void in coating film.

\subsubsection{Laitance}

A fine, whitish accumulation on concrete surfaces. It consists mainly of cement particles that were carried by water rising to the surface of freshly placed concrete.

\subsubsection{Permeability}


The measure of water or water vapor transmission rate through films of coating.

\subsubsection{Service Level II Area}

That area outside primary containment subject to radiation exposure and radionuclide contamination in accordance with ASTM D 5144.

\subsubsection{Substrate}

The base surface to which a coating is to be applied.

\subsubsection{Wet-Film Thickness}

Depth of applied coating expressed in mils measured immediately after application.

\subsubsection{Water Vapor Transmission Rate}

The steady water vapor flow in unit time through unit area of a body.

\subsection{Acronym List}

$\begin{array}{ll}\text { AIM } & \text { Architectural and Industrial Maintenance } \\ \text { ANSI } & \text { American National Standard Institute } \\ \text { ASTM } & \text { American Society for Testing and Materials } \\ \text { DF } & \text { Decontamination Factor } \\ \text { DFT } & \text { Dry Film Thickness } \\ \text { DOE } & \text { U.S. Department of Energy } \\ \text { DRD } & \text { Design Requirements Document } \\ \text { EPA } & \text { Environmental Protection Agency } \\ \text { FDNW } & \text { Fluor Daniel Northwest } \\ \text { MSDS } & \text { Material Safety Data Sheet } \\ \text { N/A } & \text { Not Applicable } \\ \text { NACE } & \text { National Association of Corrosion Engineers } \\ \text { PC } & \text { Performance Category } \\ \text { RPP } & \text { River Protection Project } \\ \text { SPC } & \text { Special Protective Coating } \\ \text { VOC } & \text { Volatile Organic Components } \\ \text { WVT } & \text { Water Vapor Transmission }\end{array}$

\subsection{Applicable Documents}

National codes and standards will be identified within Section 2, Applicable Documents, of the PDS without dates or revision numbers. Government documents and Hanford site standards will be identified by the effective date or revision number. 
HNF-SD-W314-PDS-005, Rev. 3

\section{APPENDIX A}

\section{FUNCTIONAL FLOW BLOCK DIAGRAMS (FFBDs)}

Not applicable to this specification. 
HNF-SD-W314-PDS-005, Rev. 3

APPENDIX B

REQUIREMENTS BASIS

B-1 
HNF-SD-W314-PDS-005, Rev. 3

\begin{tabular}{|c|c|c|c|}
\hline 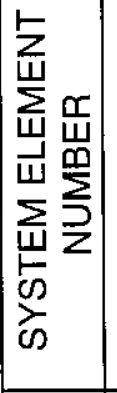 & 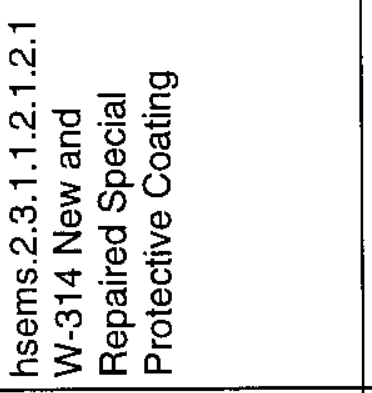 & 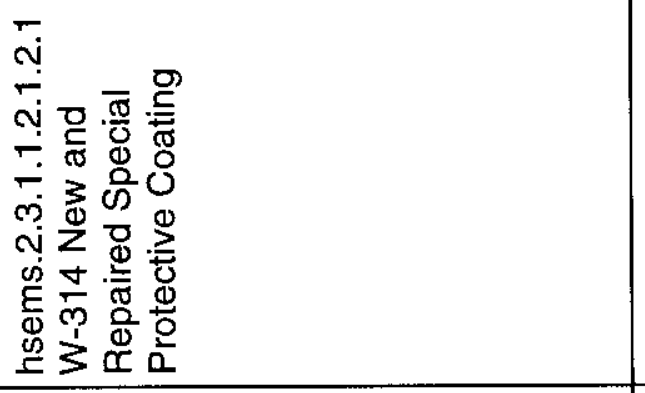 & 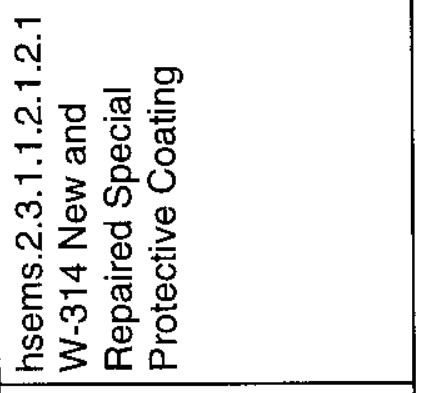 \\
\hline 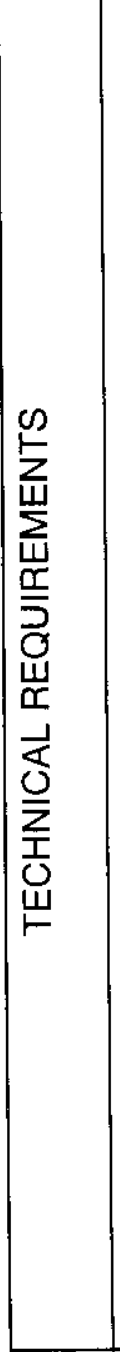 & 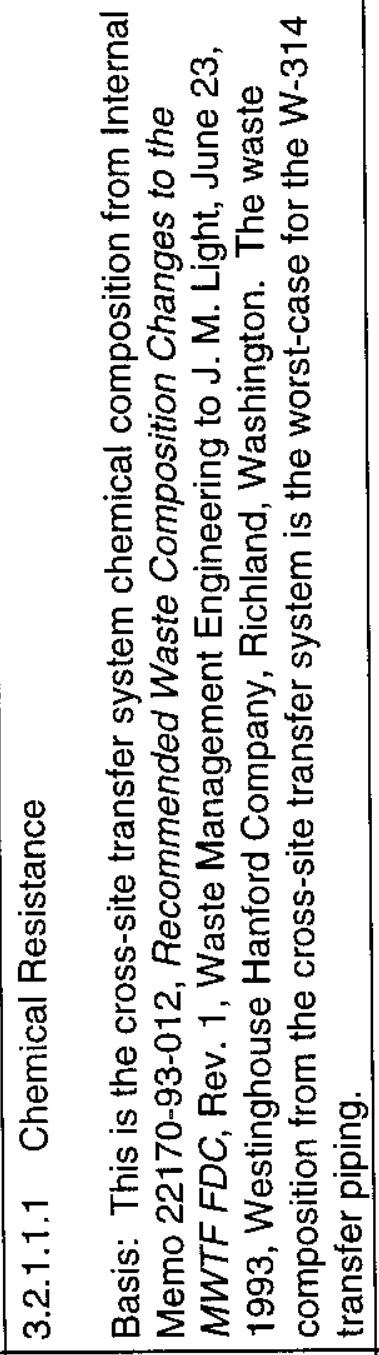 & 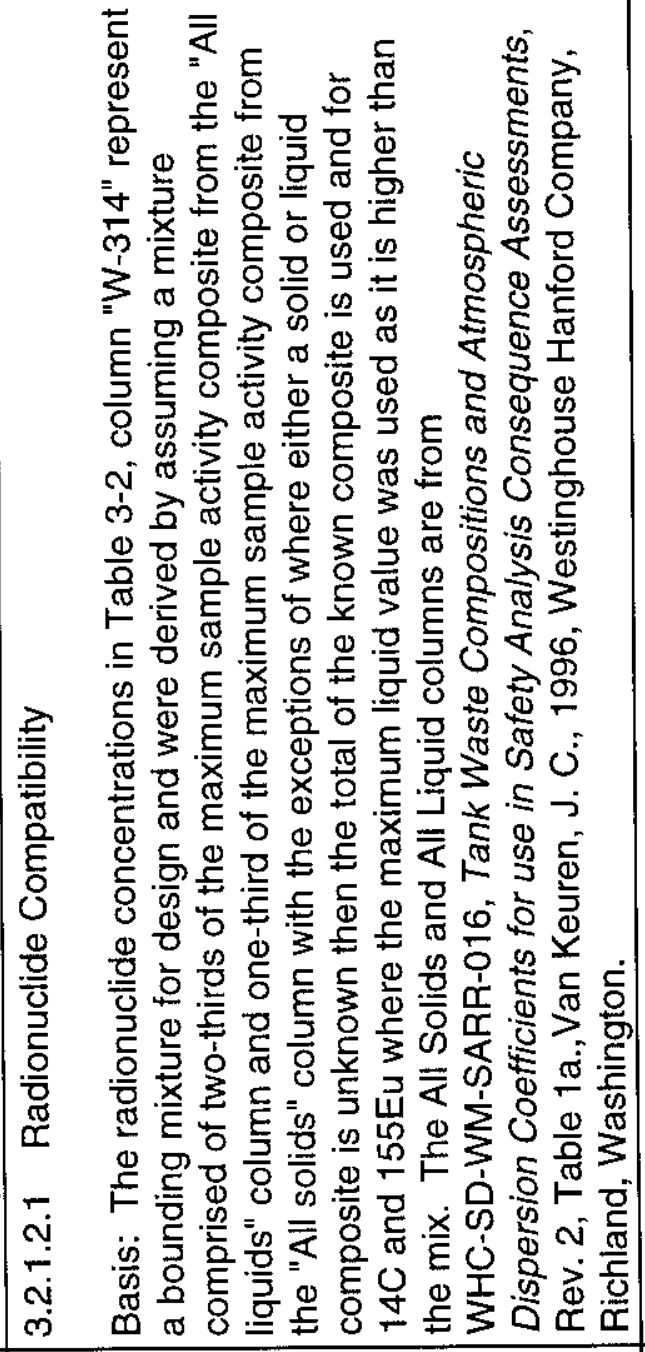 & 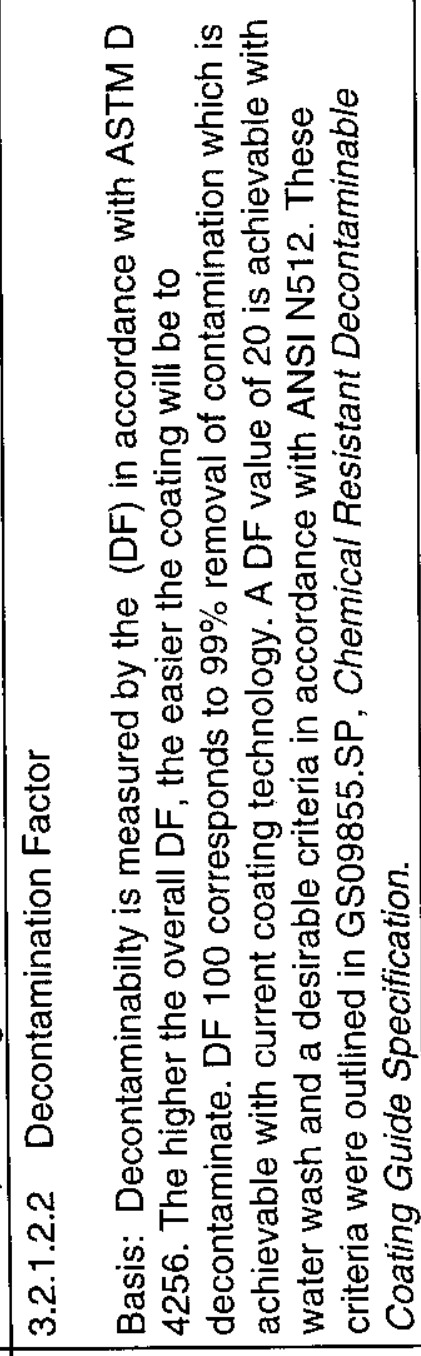 \\
\hline 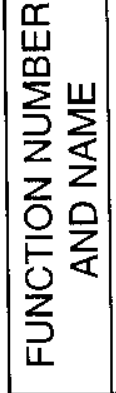 & 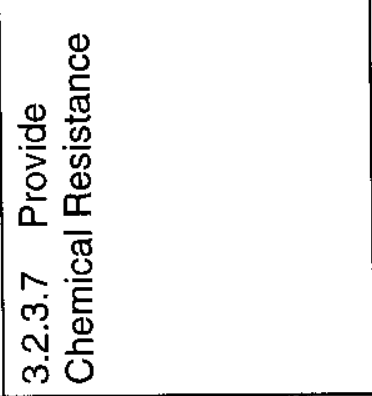 & 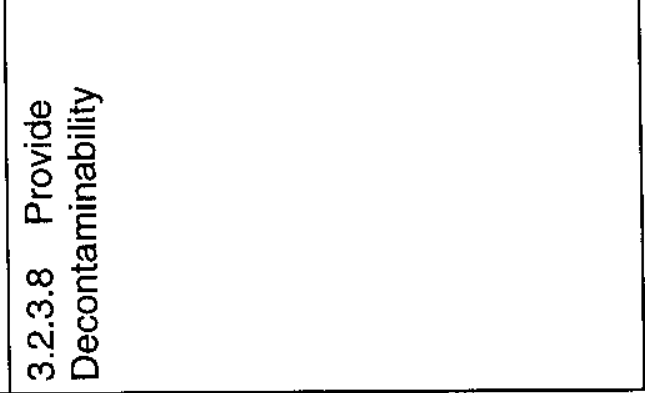 & 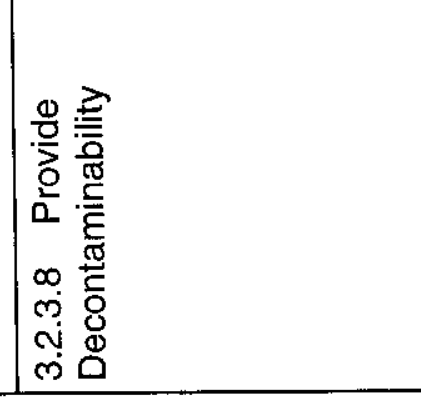 \\
\hline
\end{tabular}




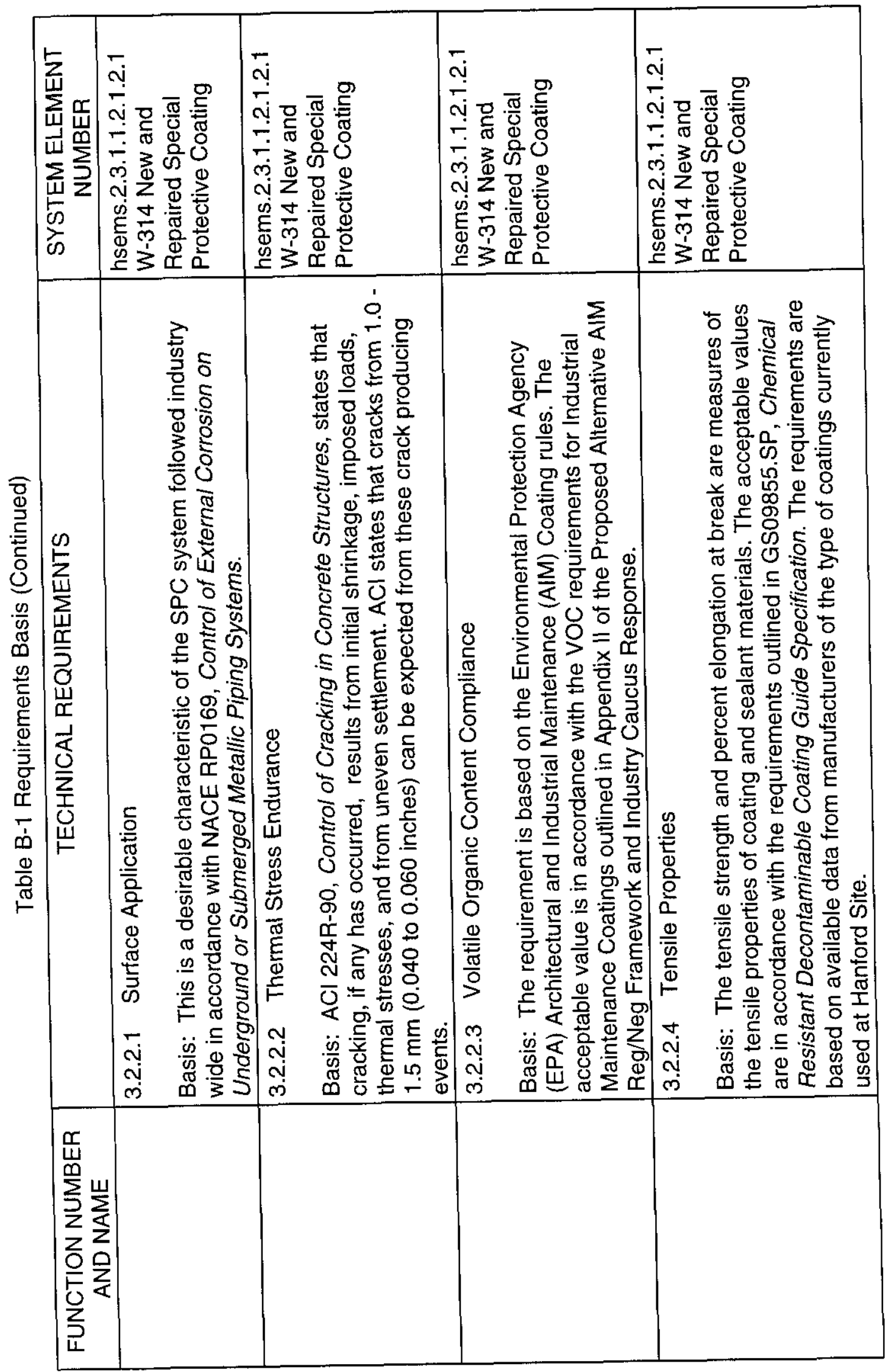


HNF-SD-W314-PDS-005, Rev. 3

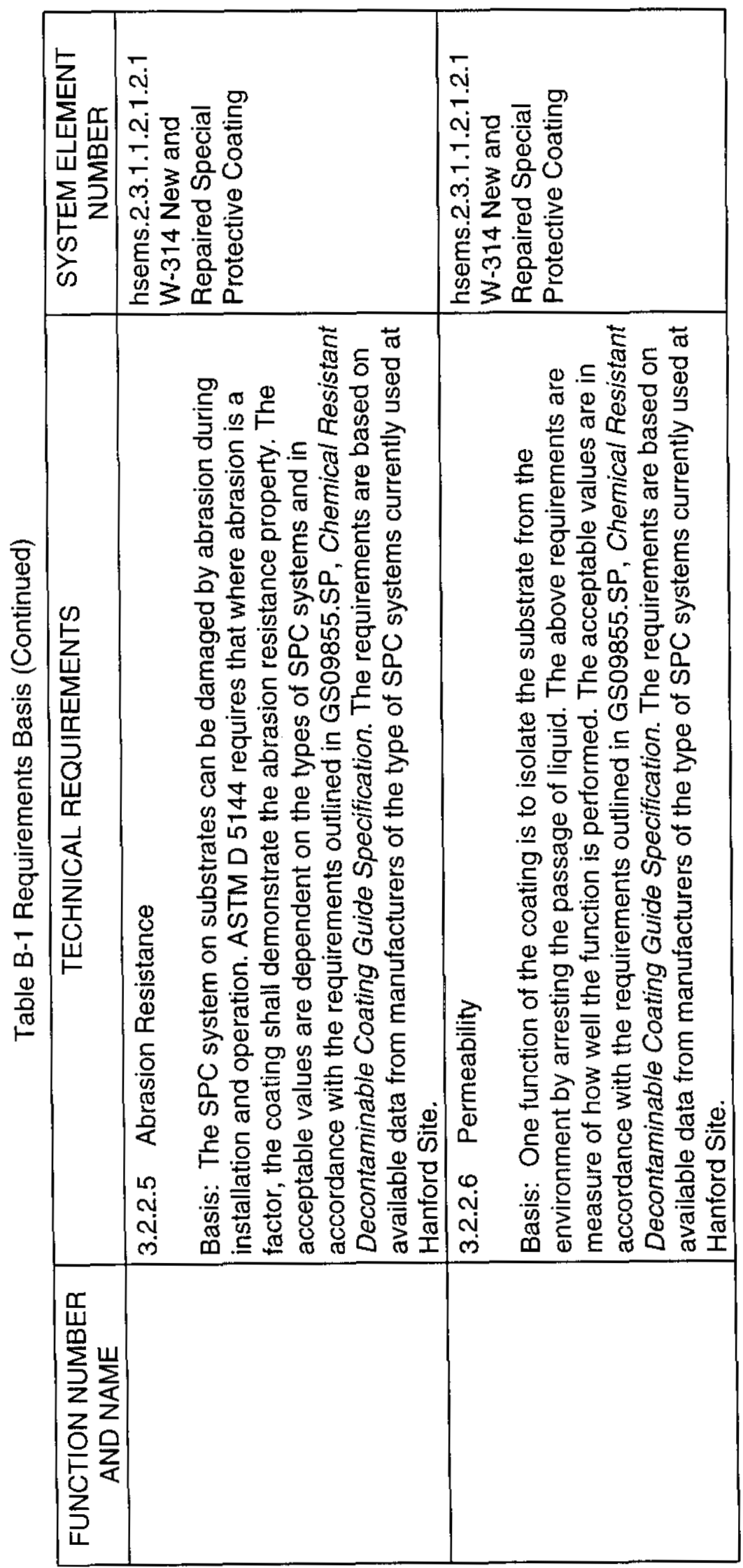


HNF-SD-W314-PDS-005, Rev. 3

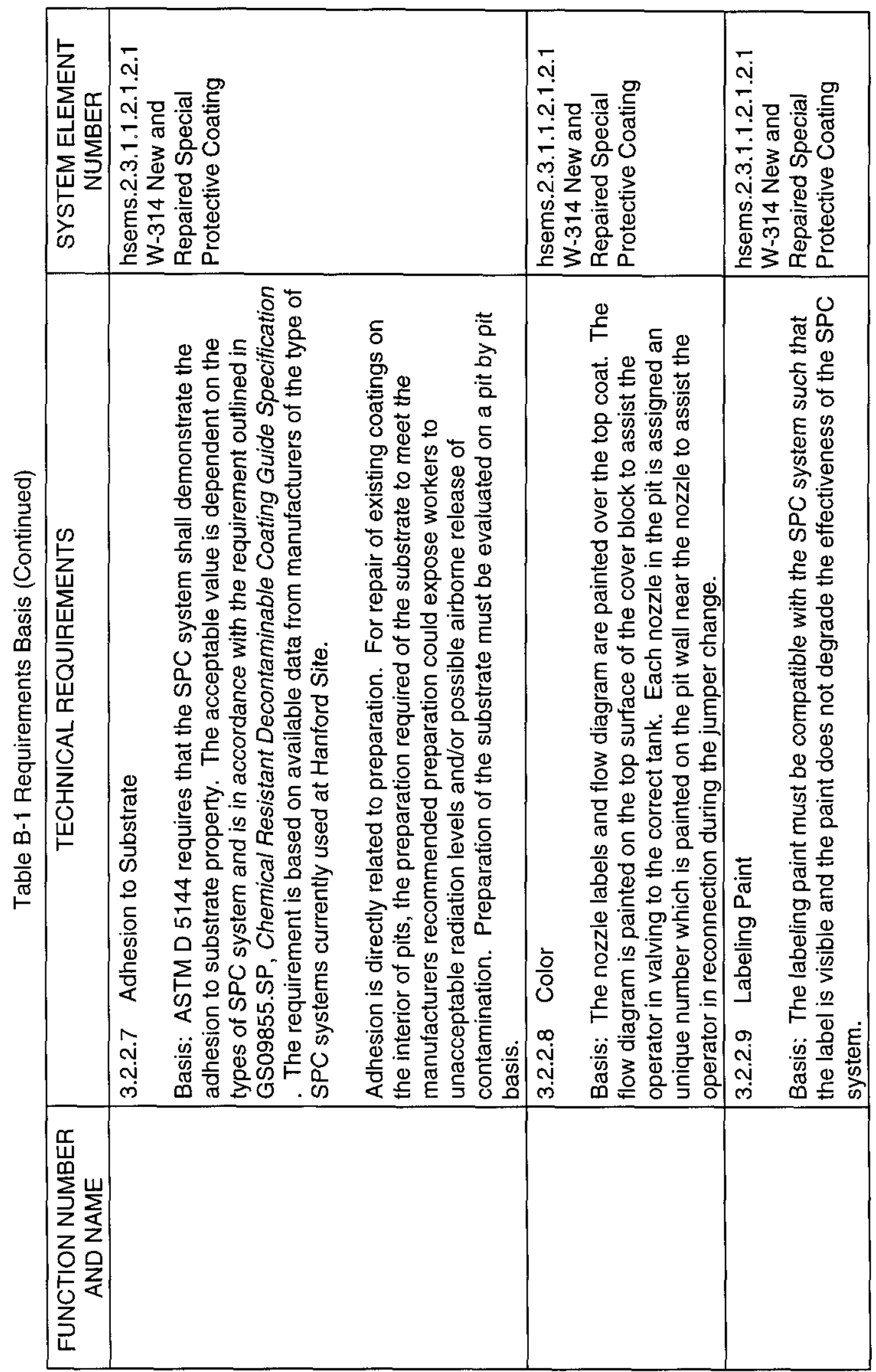




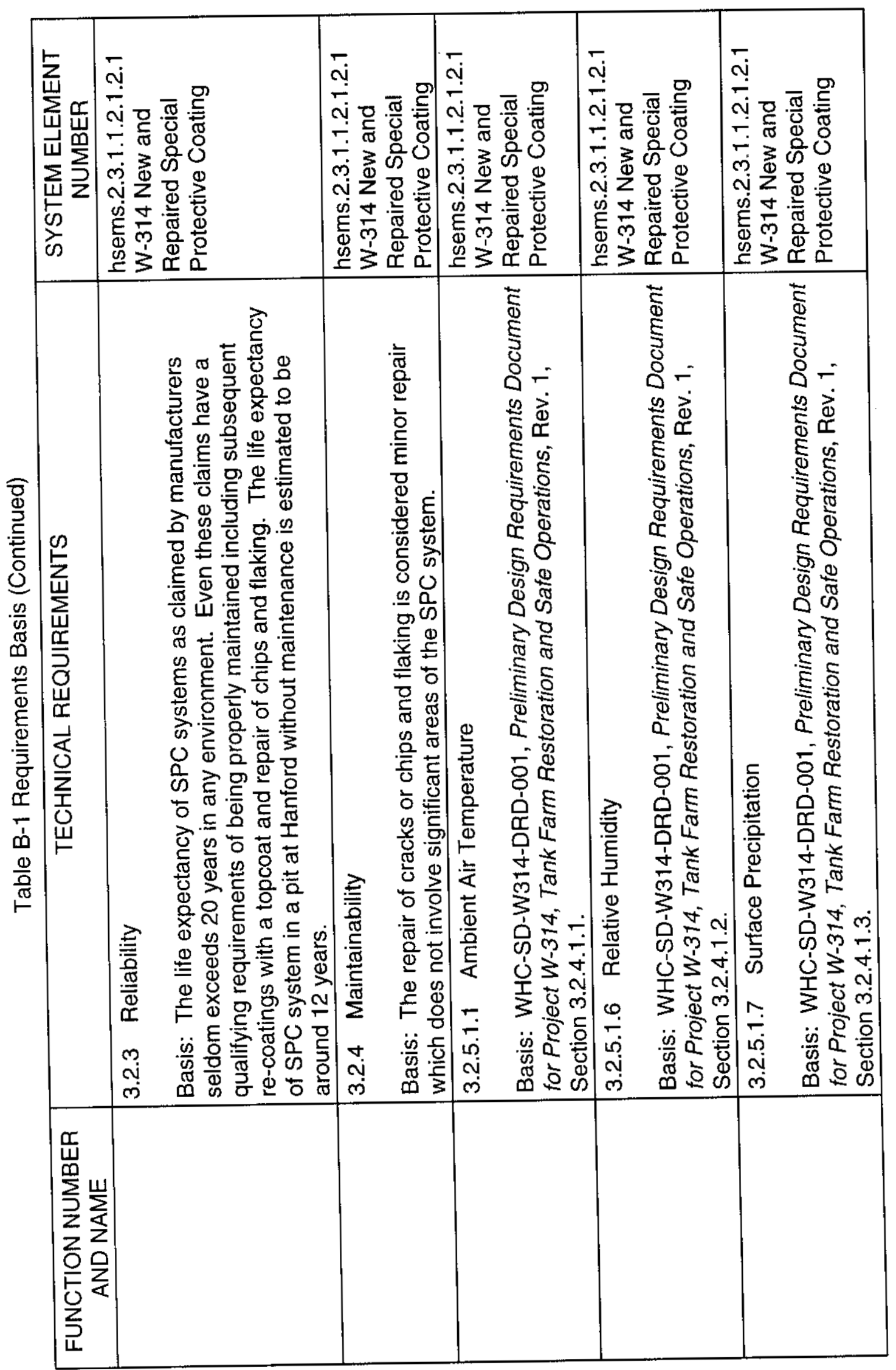




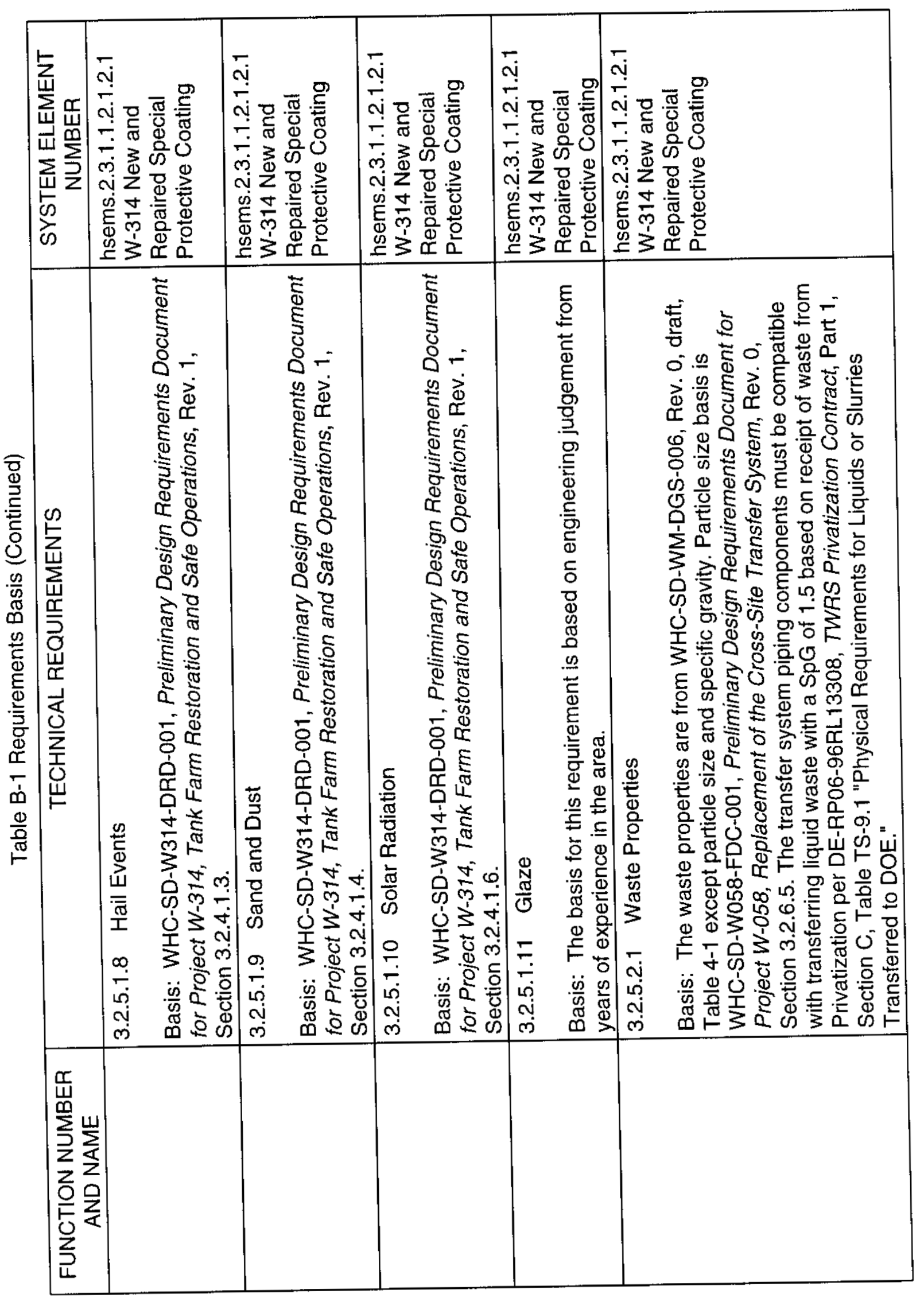




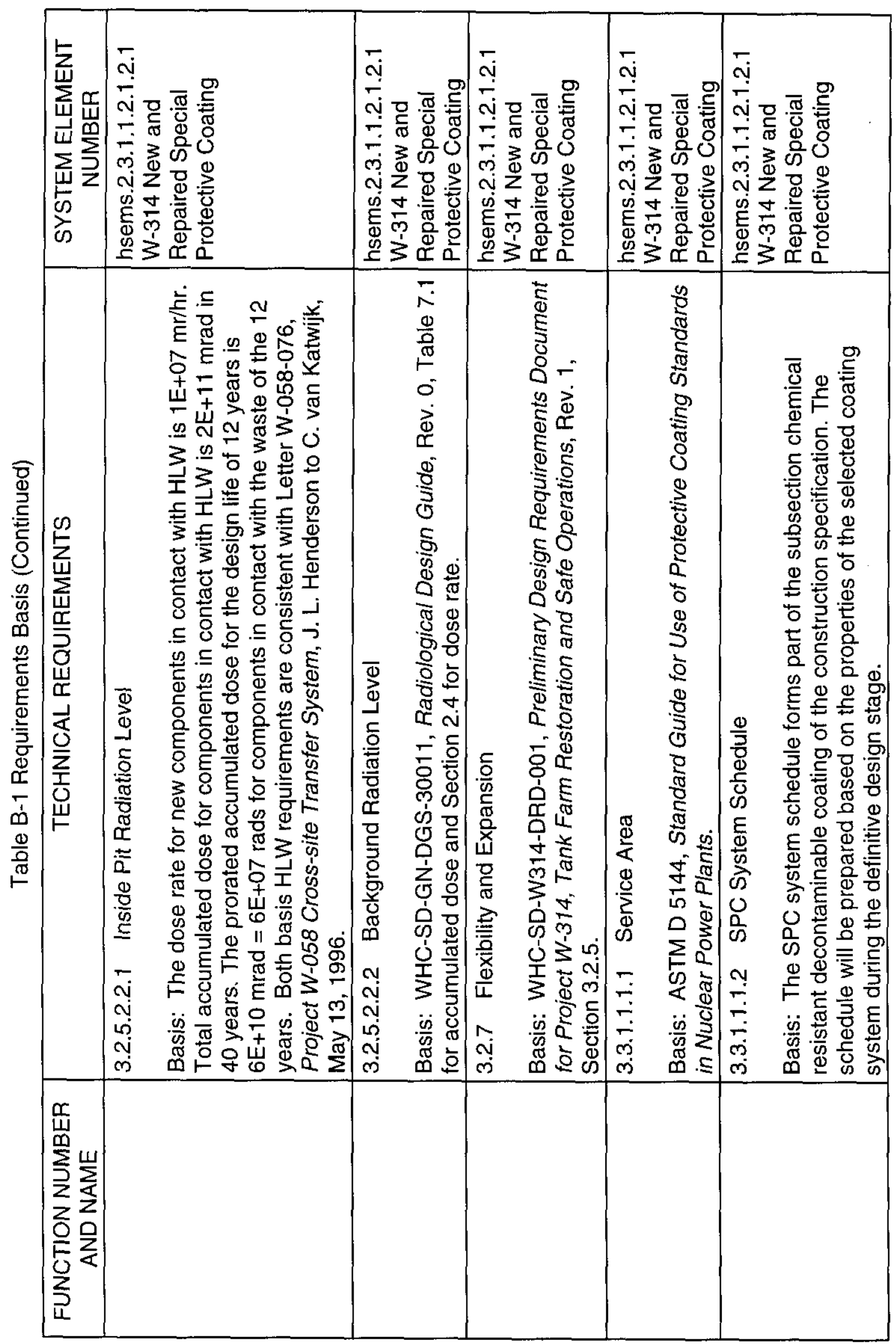




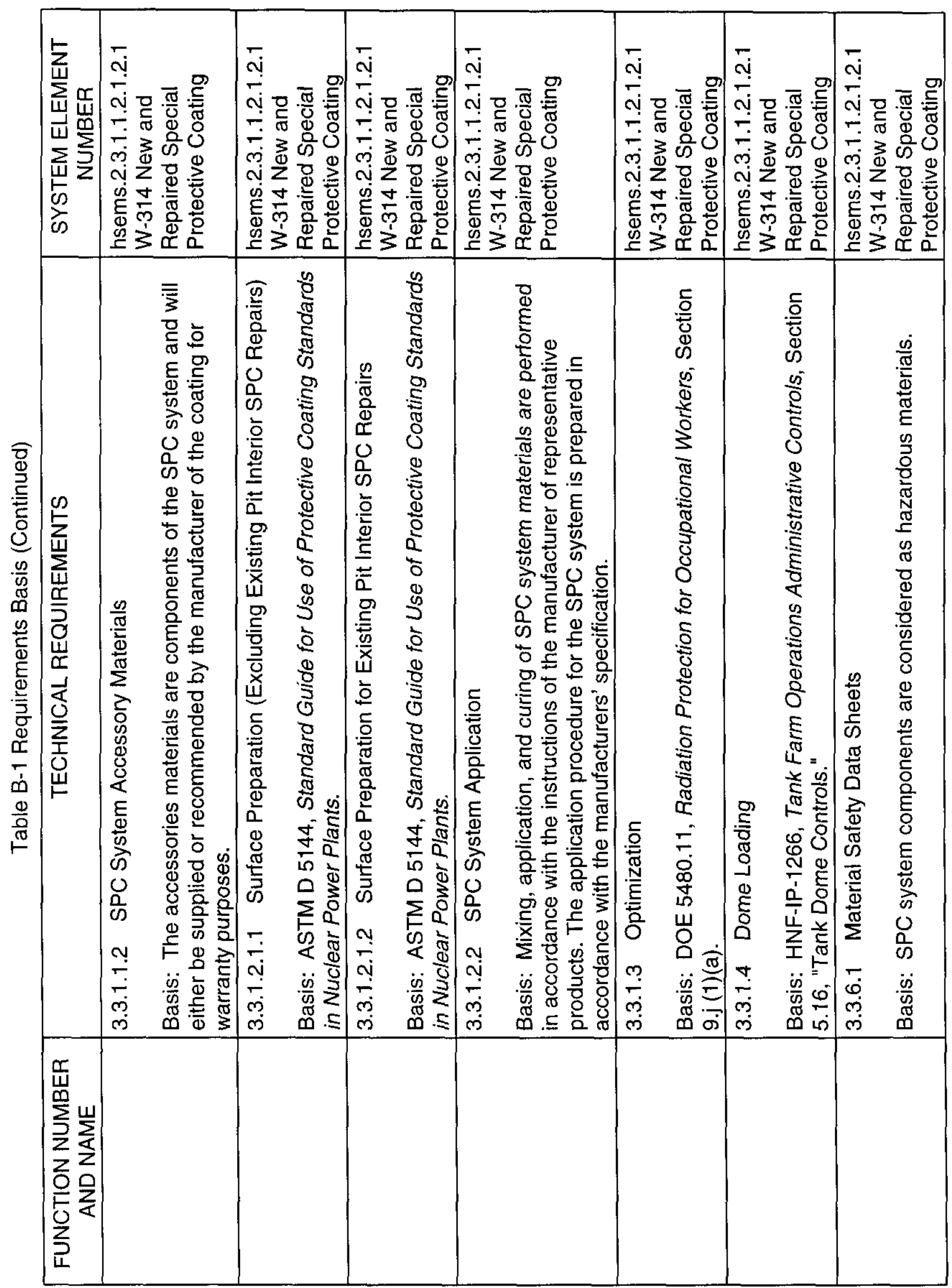


HNF-SD-W314-PDS-005, Rev. 3

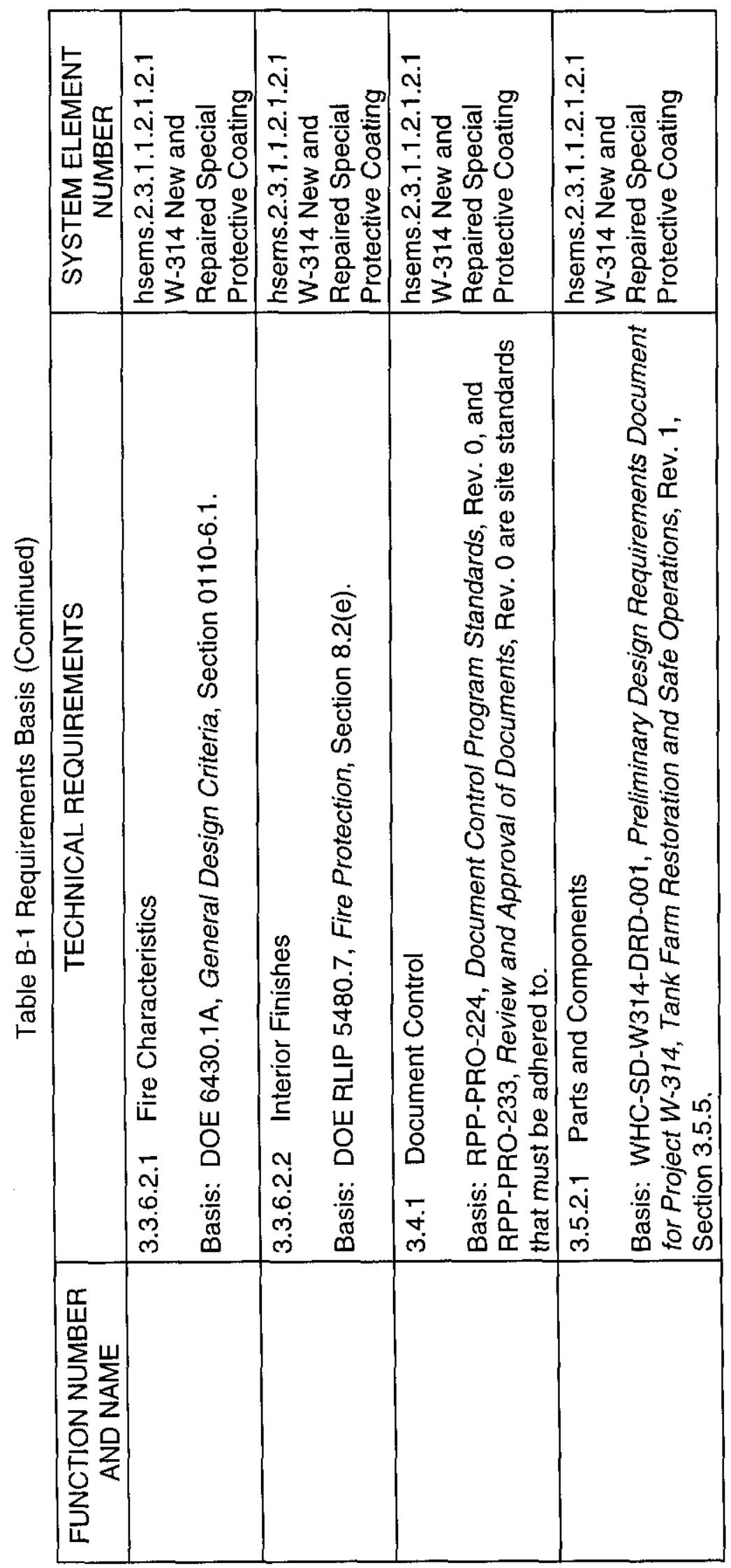

B-10 